\title{
Harmful Algal Blooms and their impacts on shellfish mariculture follow regionally distinct patterns of water circulation in the western English Channel during the 2018 heatwave
}

\author{
A. Ross Brown ${ }^{\mathrm{a}, 1,{ }^{*}}$, Martin K.S. Lilley ${ }^{\mathrm{a}, 1}$, Jamie Shutler ${ }^{\mathrm{b}}$, Claire Widdicombe ${ }^{\mathrm{c}}$, Paul Rooks ${ }^{\mathrm{c}}$, \\ Andrea McEvoy ${ }^{c}$, Ricardo Torres ${ }^{c}$, Yuri Artioli ${ }^{c}$, Gary Rawle ${ }^{\mathrm{d}}$, John Homyard ${ }^{\mathrm{e}}$, \\ Charles R. Tyler ${ }^{\mathrm{a}}$, Chris Lowe ${ }^{\mathrm{b}}$ \\ ${ }^{a}$ College of Life and Environmental Sciences, University of Exeter, Geoffrey Pope Building, Stocker Road, Exeter, Devon EX4 4QD, United Kingdom \\ ${ }^{\mathrm{b}}$ College of Life and Environmental Sciences, University of Exeter, Penryn Campus, Falmouth, Cornwall TR10 9FE, United Kingdom \\ ${ }^{\mathrm{c}}$ Plymouth Marine Laboratory, Prospect Place, The Hoe, Plymouth PL1 3DH, United Kingdom \\ d Offshore Shellfish Ltd., Brixham Laboratory, Freshwater Quarry, Brixham TQ5 8BA, United Kingdom \\ ${ }^{\mathrm{e}}$ Westcountry Mussels of Fowey Ltd., The Old Bath House, Fowey Docks, Fowey PL23 1DH, United Kingdom
}

\section{A R T I C L E I N F O}

Editor: Christopher J. Gobler.

\section{Key words:}

Climate change

HABs

Environmental factors

Shellfish poisoning

Spatial planning

Tidal front

\begin{abstract}
A B S T R A C T
Harmful algal blooms (HABs) can have severe ecological, societal and economic impacts upon marine ecosystems, human health and the seafood industry. We evaluated changes in marine plankton communities with prevailing physico-chemical conditions throughout an exceptionally warm summer (2018), to elucidate key factors governing HABs and their impacts on shellfish mariculture in the western English Channel. Despite warm, stable weather conditions and widespread seasonal stratification throughout the summer, divergent plankton community compositions were observed at two rope-grown mussel (Mytilus edulis) farms (St Austell Bay and Lyme Bay) and a long-term ecological research LTER site (Plymouth L4). There were significant differences between sites in the abundances of HAB species, including Dinophysis spp. and Karenia mikimotoi, whose cell counts bloomed in excess of UK Food Standards Agency (FSA) advisory 'trigger' levels at Plymouth L4 and St Austell Bay, but not at the Lyme Bay site. The K. mikimotoi bloom occurred over two weeks in August and comprised up to $88 \%$ of the standing phytoplankton biomass in St Austell Bay. Dinophysis spp. also bloomed here from May to September, constituting up to $28 \%$ of phytoplankton biomass. This protracted bloom resulted in concentrations of Dinophysis toxins $1 \& 2$ and pectenotoxins and okadaic acid in shellfish, which closed shellfish harvesting operations on farms located in St Austell Bay, and other shellfish sites in the west of the western English Channel (but not in the east of the region). Inter-site differences in the abundances of these and other $\mathrm{HAB}$ species were associated with variations in water circulation and co-occurring phytoplankton and zooplankton communities. Furthermore, plankton monitoring data obtained from the L4 site over the past 3 decades showed HAB species (including Dinophysis spp.) with abundances commonly occurring above advisory trigger levels during warmer periods, such as that coinciding with our study. Under projected climate warming these blooms are likely to continue to be governed by regionally distinct patterns of water circulation, which need to be taken into account in marine spatial planning, when assessing the suitability of new shellfish mariculture sites.
\end{abstract}

\section{Introduction}

Mariculture (marine aquaculture, including shellfish, finfish and macroalgal culture) is vitally important for global food security, and production from aquaculture has now overtaken capture fisheries (FAO,
2018). Mariculture, in particular, is expected to expand in the UK, with production predicted to double over the next two decades (Defra, 2017; SeaFish, 2019). Whilst the UK has an extensive coastline, with the potential to accommodate mariculture, there are numerous constraints on spatial planning/licensing (e.g. Marine Protected Areas, fishing areas,

\footnotetext{
* Corresponding author.

1 Joint first authors.
} 
shipping routes and recreational areas) and on economic productivity (e. g. local primary production, storm exposure risk and ease of access). The increasingly frequent and widespread occurrences of harmful algal blooms (HABs) is a further major constraint on mariculture in NW European shelf seas and other $\mathrm{HAB}$ hotspots relating to mariculture around the globe (Glibert et al., 2014; Weisberg et al., 2019; Trainer et al., 2020a; Wells et al., 2020).

HABs can have significant detrimental impacts on mariculture, with an annual cost of $>€ 0.03$ billion in the UK (ASIMUTH, 2014) and €0.9-1.2 billion in the EU (S-3 EuroHAB, 2019; Trainer et al., 2020b). These costs result from direct losses and from mandatory, pre-emptive harvesting closures or product recalls to prevent human poisonings from $\mathrm{HAB}$ phycotoxins that accumulate in shellfish. HAB species such as Dinophysis acuminata and Dinophysis acuta are particularly prevalent and problematic in European regional seas (Manfrin et al., 2012; Diaz et al., 2019). Above low threshold densities of 100 cells $L^{-1}$ specified in the UK (FSA, 2021), the accumulation of Dinophysis related toxins (okadaic acid, DTX derivatives and PTX) in shellfish meat can cause diarrhoetic shellfish poisoning (DSP) in human consumers (Reguera et al., 2014). Dinophysis spp. regularly bloom in the summer in sheltered coastal embayments (Raine, 2014; Schmidt et al., 2018b), and in coastal upwelling zones (Reguera et al., 2014; Diaz et al., 2019). Dinophysis blooms can also occur regularly offshore, for example at the Western Channel Observatory's L4 site (Widdicombe et al., 2010).

High biomass blooming HAB species $\left(\geq 10^{5}\right.$ cells $\left.\mathrm{L}^{-1}\right)$, such as Karenia mikimotoi, are also harmful to marine life, particularly to caged finfish or sedentary shellfish, which are unable to avoid intoxication by Karenia and/or deoxygenation of the water column, as the blooms decay (Raine et al., 2001; Silke et al., 2005; Mitchell and Rodger 2007; Coates et al., 2009; Davidson et al., 2009). Karenia mikimotoi often forms major summer blooms along the frontal boundary of the seasonally stratified western English Channel, extending from Ushant (France) to Lands End (UK), and these blooms can be advected inshore (Pingree, 1975, Holligan, 1979, Garcia and Purdie, 1994; Widdicombe et al., 2010; Barnes et al., 2015).

The increasing prevalence of warm, thermally stratified, and nutrient-limited conditions, typical of hot summers in European shelf seas, corresponding to high North Atlantic Oscillation (NAO) index values Smyth et al., 2010; Hinder et al., 2011; Barton et al., 2015; Barnes et al., 2015) is likely to select for HAB species (e.g. dinoflagellate species), whose physiologies and life-history strategies are adapted to these conditions (Gobler et al., 2020; Wells et al., 2020). For example, motile dinoflagellate HAB species, including Dinophysis spp. and Karenia mikimotoi, are able to exploit stable stratified conditions, by actively seeking light and inorganic nutrients for photosynthesis, and also preying upon other plankton (mixotrophy) (Anderson et al., 2012; Zhang et al., 2013; Lucas et al., 2016). Increased sea surface warming can also alter the position and intensity of tidal mixing fronts dividing mixed and stratified water masses (Sharples and Simpson, 2019), with the potential to expand niches for HAB species into otherwise well mixed coastal and shelf sea areas, not previously considered to be bloom hotspots. Understanding the degree to which environmental warming may expand niches for HABs both spatially and temporally will be critically important for predicting and mitigating future HAB impacts on existing mariculture operations and for marine spatial planning for enabling the sustainable growth of the industry (Brown et al., 2019; Wells et al., 2015; 2020). HAB occurrences may be driven by multiple additional factors, some potentially relating to mariculture, including habitat disturbances and coastal eutrophication (Hallegraeff, 2010; Anderson, 2012; Gowen et al., 2012; Davidson et al., 2014; Brown et al., 2019). Therefore, discerning climate-driven changes in HAB risk for shellfish growing areas ideally requires analysis of multi-decadal data (Barton et al., 2015; Dees et al., 2017). Some understanding of future HAB risk can also be gained from studying extreme events (e.g. exceptionally warm periods), representing significant departures from long-term means and resembling possible future climate scenarios under which
HABs could develop (Trainer et al., 2020a).

Here, our broad aim was to examine the potential impact of warming on the occurrence of HABs at shellfish aquaculture sites in SW England. To do this, we opportunistically surveyed two shellfish aquaculture sites in St Austell Bay (SAB) and Lyme Bay (LB), and a long-term ecological research (LTER) site (Plymouth L4), during the unusually warm summer of 2018. The decade 2009-2018 was the warmest on record in the UK, $i$. e. $0.3^{\circ} \mathrm{C}$ warmer than the $1981-2010$ average and $0.6{ }^{\circ} \mathrm{C}$ warmer than 1961-1990 (Kendon et al., 2019). Summer 2018 coincided with the highest summer North Atlantic Oscillation (NAO) index since 1955, which led to the northward displacement of Atlantic storm tracks, exceptionally calm conditions and elevated sea surface temperatures around the UK and across the NW European shelf (Kendon et al., 2019). These conditions resemble future climate change scenarios for the region (Tinker et al., 2016; UKCP018; Kendon et al., 2019). The sites surveyed in our study span a frontal region around Start Point $\left(\sim 4^{\circ} \mathrm{W}\right.$, Fig. 1), which separates predominantly summer-stratified water to the west and predominantly mixed waters to the east (Pingree et al., 1983; Boalch 1987). Historically, these shellfish sites have shown contrasting patterns of $\mathrm{HAB}$ exposure, suggesting that the frontal region may present a boundary for dispersal of bloom forming species in the region. Consequently, our first aim was to examine the physio-chemical properties, plankton community composition, and occurrence of HABs at each site in order to assess the degree of similarity/dissimilarity between sites during the exceptionally warm and stable period from May to August 2018. To place the survey in a broader regional and temporal context, we examined HAB cell counts and/or biotoxin concentrations recorded by the UK Food Standards Agency (FSA) for the region during the 2018 sampling period - to assess the prevalence of HABs across the Start Point frontal region. In addition, we examined the abundance of $\mathrm{HAB}$ species at the long-term L4 monitoring site over a $\sim 30$ year period to assess whether extended periods of summer stratification are typically associated with increases in the abundance or persistence of dinoflagellate HAB species, which are known to exploit warm water conditions (Hallegraeff, 2010; Hinder et al., 2011; Glibert et al., 2014; Wells et al., 2015; Gobler et al., 2017).

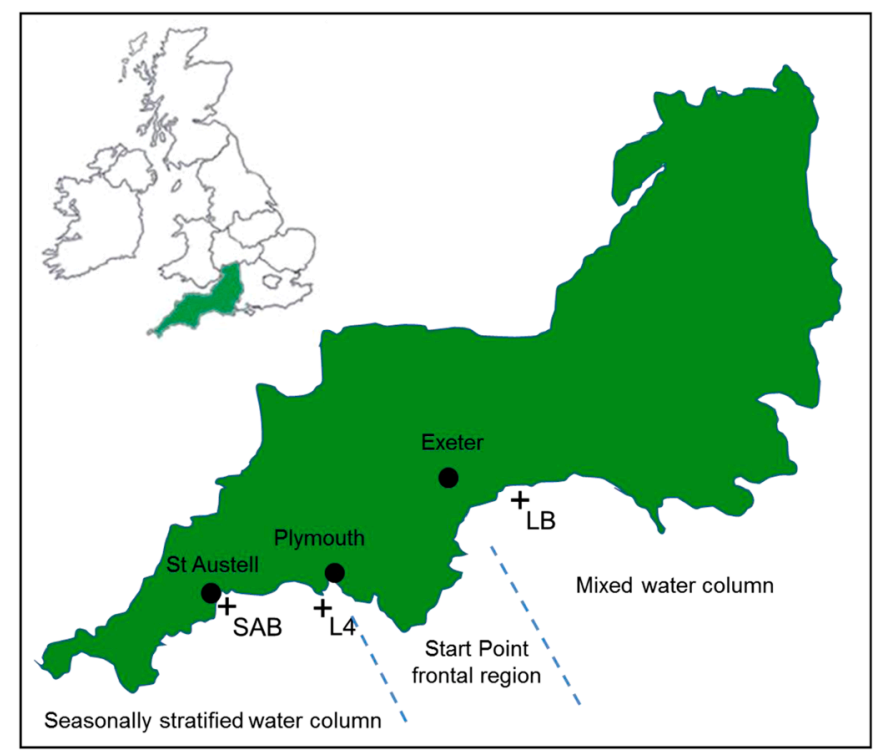

Fig. 1. Sampling site locations - St Austell Bay (SAB), Plymouth (L4) and Lyme Bay (LB). Note: All three study sites exhibit seasonal stratification of the water column, including LB, which is relatively sheltered from wind and tide in an otherwise generally mixed region. 


\section{Methods}

\subsection{8 survey}

\subsubsection{Sampling points}

Surveys were conducted at three sites; St Austell Bay (SAB), Plymouth (L4) and Lyme Bay (LB) located on the South coast of SW England (Fig. 1). SAB and LB are shellfish mariculture sites for rope-grown mussels (Mytilus edulis). The following is a brief description of the sites (for detailed site descriptions refer to Table 1). The SAB and LB sites are located $2.5 \mathrm{~km}$ and $8 \mathrm{~km}$ from shore, respectively. Both are within UK territorial waters $(22.2 \mathrm{~km} \approx 12$ nautical miles) and are considered coastal mariculture sites (Buck et al., 2018). The third site (L4), part of the Western Channel Observatory (WCO), is a long-term ecological research (LTER) site (where no mariculture is practised), located $7.6 \mathrm{~km}$ off Penlee Point at the entrance to Plymouth Sound (WCO, 2020). SAB is a relatively sheltered site and is less exposed to mixing by prevailing SW winds and tidal streams compared to L4 \& LB. Sampling at each site was conducted at paired stations (Stations 1 and 2, see Table 1). Station 1 corresponded to the FSA-designated Representative Monitoring Point for each mariculture site and the WCO-designated monitoring point at L4. Station 2 was sampled to provide additional data on local $(1-10 \mathrm{~km})$ spatial variation in physico-chemical parameters (Sections 2.1.2 and 2.1.3). Sampling was conducted for 15 consecutive weeks, from week 21 in May to week 35 at the end of August in 2018. Sampling at L4 corresponded with scheduled WCO monitoring, while sampling at the mariculture sites $\mathrm{LB}$ and $\mathrm{SAB}$ corresponded with scheduled $\mathrm{HAB}$ and phycotoxin monitoring coordinated by the FSA.

\subsubsection{Sampling methods}

At paired sampling stations, at each shellfish site, profiles of temperature and salinity with water depth were obtained using a handdeployed CastAway ${ }^{\mathrm{TM}}$ (SonTek, San Diego, CA) conductivity temperature depth (CTD) probe. The intensity of stratification was estimated as the difference in density at water column depths of $2 \mathrm{~m}$ and $10 \mathrm{~m}$. On each sampling occasion, the time of high water, weather conditions (cloud cover, wind speed, direction), Secchi depth, sea state (wave height), and tidal height were recorded. Water samples were collected from depths of $2 \mathrm{~m}$ and $10 \mathrm{~m}$ using a hand-deployed $5 \mathrm{~L}$ Niskin bottle (General Oceanics, Miami, FL). Each water sample was split into aliquots for inorganic nutrient, chlorophyll- $a$, and phytoplankton analysis. Chlorophyll and nutrient samples were kept refrigerated for up to $24 \mathrm{~h}$ before filtration and storage at $-20{ }^{\circ} \mathrm{C}$. Phytoplankton samples were preserved directly in $2 \%$ (final concentration) acid Lugol's iodine, in amber glass bottles and stored in the dark. Samples for zooplankton community analysis were collected (Station 1 only) using verticallyhauled $500 \mathrm{~mm}$ diameter WP2-style ring net $(200 \mu \mathrm{m}$ mesh size $)$ (NHBS, Totnes, UK) from approximately $2 \mathrm{~m}$ from the sea bed to the surface. Zooplankton samples were washed off the $200 \mu \mathrm{m}$ mesh collector with seawater and immediately preserved in $4 \%$ formaldehyde (final concentration) in a $250 \mathrm{~mL}$ bottle. At the Plymouth L4 site, sampling was conducted as part of the regular WCO monitoring programme according to WCO protocols (Smyth et al., 2015).

\subsubsection{Nutrient and chlorophyll analysis}

Nutrient samples were analysed by the UK Environment Agency National Laboratory Service (Starcross, UK): nitrate, nitrite, ammonium, silicate and total phosphate were determined colorimetrically using a continuous flow (CF) autoanalyser (EA, 2019). Chlorophyll- $a$ was measured by fluorescence spectrophotometry, following the protocol of Holm-Hansen et al. (1965) using 90\% ice-cold acetone as a solvent. Excitation/emission $(430 / 664 \mathrm{~nm})$ measurements were made using Spectromax M5 spectrophotometer (Molecular Devices, UK) and Chl- $a$ distinguished from pheopigments using the $\mathrm{HCl}$ addition method. Chl- $a$ concentrations were estimated against known standards made from pure Chl- $a$ (CAS Number 479-61-8, obtained from Sigma-Aldrich, UK).

\subsubsection{Phytoplankton and zooplankton enumeration}

Plankton samples were analysed at Plymouth Marine Laboratory using the same WCO protocols for all sites. Phytoplankton counts were performed using the Utermöhl technique (Utermöhl, 1958) following the British and European Standard protocol (BS EN 15204:2006). $50 \mathrm{~mL}$ sub-samples were obtained after gently stirring each bulk sample (to ensure homogeneity) and then settled (for $24 \mathrm{~h}$ ) prior to examination using an inverted microscope $(100 \times$ magnification $)$ and identifications were made to species level were possible. Species abundances were expressed per $\mathrm{mL}$ of water and as carbon biomass ( $\mathrm{mg} \mathrm{C} \mathrm{m}^{-3}$ ) following Menden-Deuer and Lessard (2000).

Zooplankton were identified to the lowest practicable taxonomic resolution and enumerated under an inverted microscope $(100 \times$ magnification). Subsamples were extracted with a Hensen-Stempel pipette achieving between 200 and 400 individuals. Larger subsamples were checked for larger and/or rarer species. Abundance was expressed as numbers of organisms per cubic metre (abundance $m^{-3}$ ). The HAB species Noctiluca scintillans was quantified in zooplankton as well as phytoplankton samples, due to these large dinoflagellates $(>200$ $\mu \mathrm{m}$ diameter) being caught in the zooplankton net.

\subsubsection{Survey data analysis}

Statistical analyses were performed on the 2018 survey data

Table 1

Physical characteristics of the study sites at St Austell Bay (SAB), Plymouth (L4) and Lyme Bay (LB).

\begin{tabular}{|c|c|c|c|}
\hline Site & St Austell Bay (SAB) & Plymouth (L4) & Lyme Bay (LB) \\
\hline \multicolumn{4}{|c|}{ Location (lat, long) } \\
\hline Station 1 & $50.315 \mathrm{~N}, 4.717 \mathrm{~W}$ & $50.250 \mathrm{~N}, 4.217 \mathrm{~W}$ & $50.573 \mathrm{~N}, 3.214 \mathrm{~W}$ \\
\hline Station 2 & $50.309 \mathrm{~N}, 4.735 \mathrm{~W}$ & $50.316 \mathrm{~N}, 4.174 \mathrm{~W}$ & $50.639 \mathrm{~N}, 3.184 \mathrm{~W}$ \\
\hline Category $^{1}$ & Coastal & Offshore & Coastal \\
\hline Distance & $2.5 \mathrm{~km}$ from shore & $7.6 \mathrm{~km}$ from shore & $8.5 \mathrm{~km}$ from shore \\
\hline Depth & $\sim 21 \mathrm{~m}$ & $\sim 55 \mathrm{~m}$ & $\sim 25 \mathrm{~m}$ \\
\hline OSPAR region & II - Greater North Sea & II - Greater North Sea & II - Greater North Sea \\
\hline $\begin{array}{l}\text { UK Env Agency } \\
\text { region }\end{array}$ & West Inshore region & Not monitored & East Inshore region \\
\hline $\begin{array}{l}\text { OSPAR } \\
\text { stratification }\end{array}$ & Indeterminate density & Indeterminate density & Intermittent density \\
\hline $\begin{array}{l}\text { Thermal } \\
\text { stratification }\end{array}$ & Seasonal & Seasonal & Seasonal \\
\hline
\end{tabular}

${ }^{1}$ Offshore defined by water depth $>30 \mathrm{~m}$ (Froehlich et al., 2017). Lyme Bay could be defined as offshore based on current speed ( $>0.2 \mathrm{~m} / \mathrm{s}$ ), but based on water depth $(<30 \mathrm{~m})$ it is considered a coastal site (Froehlich et al., 2017). 
primarily using Primer-E (v.6) statistical software (Clarke et al., 2014) and R v3.6.3 (R Core Team, 2017). To examine the degree of similarity in the physico-chemical environmental characteristics of each site, a principle component analysis (PCA) was performed on normalised salinity, temperature, density, Chl- $a$ and Secchi depth (a proxy for turbidity) data recorded each week at both $2 \mathrm{~m}$ and $10 \mathrm{~m}$ depth over the course of the 15 week monitoring period.

Plankton community composition at each site, and differences between sites, were examined using abundance and carbon biomass data. Briefly, the following multivariate statistical analyses were performed following square-root transformation of the data to reduce bias from high abundance (or high biomass) species on the analytical results. We tested dissimilarities in plankton community composition between sampling sites using Bray Curtis similarity-based cluster analysis and Multi-Dimensional Scaling ordination. Permutational Multivariate Analysis of Variance (PERMANOVA, 2-way analysis with weekly samples nested within sites and accounting for random effects associated with repeated measures) was used to test $a$ priori for significant differences between sampling sites (SAB, L4 and LB). Contribution of key taxa to $\%$ similarity of time-series data for each sampling site and $\%$ dissimilarity between sites was assessed post hoc using SIMPER.

\subsection{Analysis of temporal and wider spatial variations in HABs and oceanographical conditions}

\subsubsection{Plankton monitoring data}

The UK Food Standards Agency HAB monitoring data from SAB, LB and other designated shellfish sites in SW England (FSA, 2019) were used to evaluate spatial variations in HAB species abundance during the summer of 2018 and in preceding years. Long-term plankton monitoring data (1993-2018) from the Western Channel Observatory's L4 site (WCO, 2020) were used to evaluate temporal variations in HAB species abundance in relation to local variations in sea surface temperature measured every week via CTD profiling. HAB species (cell) abundances recorded each week were compared to UK Food Standards Agency (FSA) advisory trigger levels indicative of elevated concentrations of phycotoxins in shellfish that may poison human consumers (FSA, 2021). We determined how frequently trigger levels were breached for individual $\mathrm{HAB}$ species each year leading up to 2018. Although there is a lack of scientific understanding of phycotoxin production in $K$. mikimotoi, an arbitrary trigger level of 150,000 cells $\mathrm{L}^{-1}$ is adopted for this species (FSA, 2021). HAB species (cell) abundances were also compared with water temperature at $10 \mathrm{~m}$ depth - using paired-sample Pearson correlations based on untransformed (normal) data from 2002 to 2018, during which cell abundances and water temperature have been sampled concurrently.

\subsubsection{Satellite monitoring data and coastal circulation model outputs}

The extent of major plankton blooms in the western English Channel in spring and summer 2018 was defined by Sentinel-3A ocean and land colour images (OLCI) presented in enhanced colour (Level 2) by the NERC Earth Observation Data Acquisition and Analysis Service (NEODAAS), hosted at Plymouth Marine Laboratory and overseen by NERC's National Centre for Earth Observation (NCEO) (https://neodaas.ac.uk/ Home). To help identify possible links between the distribution of major (visible) plankton blooms and water circulation patterns in the western English Channel, daily mean surface current velocities (net flows at $0 \mathrm{~m}$ and $15 \mathrm{~m}$ water depth) were obtained from a REP L4 global total velocity field $\left(0.25^{\circ}\right.$ regular grid), derived by Rio et al. (2014) and available from the EU Copernicus Marine Service Information (CMEMS, 2020). Velocities combined CMEMS REP satellite Geostrophic surface currents and modelled Ekman currents (using ECMWF ERA5 wind stress). These velocity data inherently include large-scale thermohaline circulation and wave-driven Stokes drift, and exclude oscillating tidal flows. Data from each site were aggregated in weeks or months (as required) and were plotted on a compass rose using 'windRose' in the $\mathrm{R}$ package 'openair' v.2.7-2 (http://davidcarslaw.github.io/openair/) built in $\mathrm{R}$ version 3.6.3. A regional-scale assessment of the surface current velocities (based on the CMEMS data) was made using the European Space Agency's Ocean Virtual Laboratory (https://ovl.oceandatalab. $\mathrm{com} /$ ).

\section{Results}

\subsection{8 survey campaign}

\subsubsection{Physico-chemical conditions}

PCA showed that $32.5 \%$ of variation in the combined physicochemical data was captured in PC1, while $25.9 \%$ was captured in PC2. PC1 reflects similar temporal changes across all three sampling sites in terms of water temperature, salinity and density (Fig. 2). The intensity of stratification at each site was measured as the differential between lower density surface water at $2 \mathrm{~m}$ and higher density deeper water at $10 \mathrm{~m}$ (i. e. delta density @ 10m-2 m). During the period from week 21 (beginning of May) until Week 31 (beginning of August), stratification intensified with increasing sea surface temperature $(2 \mathrm{~m}$ depth), rising from $12{ }^{\circ} \mathrm{C}$ to $>18.5{ }^{\circ} \mathrm{C}$ at SAB and $\mathrm{LB}$ and from $12{ }^{\circ} \mathrm{C}$ to $>19{ }^{\circ} \mathrm{C}$ at L4. Stratification was (apart from week 29) amplified when tidal mixing was reduced during neap tidal cycles (Fig. 2). The depth of the thermocline at each site varied between 5 and $15 \mathrm{~m}$ (depending on tidal cycles) and occurred most frequently at a water depth of around $10 \mathrm{~m}$ (SI Figure S1).

PC2 reflects temporal changes characterised for the most part by reducing Chl- $a$ concentration (from 1 to 0.5 to $0.1 \mathrm{mg} \mathrm{Chl-a} \mathrm{m}^{-3}$ ) and increasing Secchi depth, which reached maxima of $13.5 \mathrm{~m}$ depth at $\mathrm{SAB}$, $12 \mathrm{~m}$ at L4 and $17.5 \mathrm{~m}$ at LB (SI Figure S2). Chl- $a$ concentration and stratification intensity were generally greatest at SAB, followed by L4 and then LB (Fig. 2). Greatest stratification at SAB coincided with reduced surface salinity, following rainfall events in weeks 24 and 29, and corresponded with elevated nutrient (ammonium and phosphate) concentrations in near-surface water samples (SI Figure S2, Table 2). Other than these occasional brief increases in concentrations, nutrients remained for the most part at or below detectable levels throughout the survey period and were therefore excluded from the PCA. Concordant with low nutrient levels, Chl- $a$ concentrations (at both $2 \mathrm{~m}$ and $10 \mathrm{~m}$ ) were generally low $\left(<1 \mathrm{mg} \mathrm{m}^{-3}\right.$ ) for the majority of the monitoring period. However, Chl- $a$ concentrations rose sharply at the two westernmost sites in mid-August (week 33), coinciding with a sudden reduction in water temperature and a noticeable increase in nutrient concentrations at L4 (Table 2).

\subsection{2. $H A B$ occurrence and abundance}

The spike in Chl- $a$ concentrations in mid-August (week 33) coincided with a high biomass $K$. mikimotoi bloom at $\mathrm{SAB}\left(457 \mathrm{mg} \mathrm{C} \mathrm{m}^{-3}\right)$ and at $\mathrm{L} 4$ $\left(128 \mathrm{mg} \mathrm{C} \mathrm{m}^{-3}\right.$ ); corresponding cell counts for $K$. mikimotoi exceeded advisory trigger levels of 150,000 cells $\mathrm{L}^{-1}\left(\mathrm{SAB}=737,000\right.$ cells $\mathrm{L}^{-1}$; L4 $=151,000$ cells L $^{-1 ;}$ ) (Fig. 3). High biomass blooms of Noctiluca scintillans ( $>150,000$ cells $\mathrm{L}^{-1}$ ) were also recorded at L4 and SAB in late July and during August (weeks 30-34). Low biomass blooming dinoflagellate species (Dinophysis acuminata followed by Dinophysis acuta) breached trigger levels of 100 cells $\mathrm{L}^{-1}$ at $\mathrm{L} 4$ (up to 3300 cells $\mathrm{L}^{-1}$ ) and SAB (up to 6900 cells $\mathrm{L}^{-1}$ ) over the entire monitoring period (Fig. 3), leading to the accumulation of Dinophysis related toxins (okadaic acid, DTX derivatives and PTX) in shellfish and the closure of mussel farms in SAB throughout the summer. Another low biomass dinoflagellate HAB species Prorocentrum cordatum bloomed in late May/early June and breached trigger levels of 100 cells $\mathrm{L}^{-1}$ at $\mathrm{L} 4$ (up to 1480 cells $\mathrm{L}^{-1}$ ), SAB (up to 3560 cells $\mathrm{L}^{-1}$ ) and LB (up to 480 cells $\mathrm{L}^{-1}$ ) (Fig. 3). Diatom HABs Pseudo-nitzschia spp. were also recorded all three sampling sites and in late June/early July (week 26 and week 27) at modest biomasses of 0.8 to $1.2 \mathrm{mg} \mathrm{C} \mathrm{m}^{-3}$ and abundances of 25,000 to 35,000 cells L $^{-1}$, but these were substantially below advisory trigger levels of 150,000 cells $\mathrm{L}^{-1}$ 


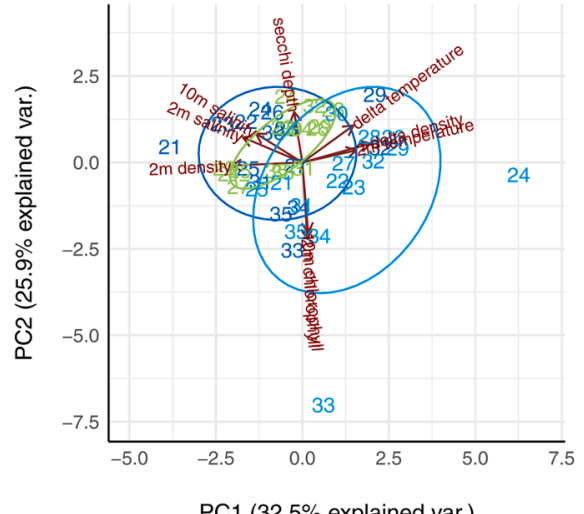

PC1 (32.5\% explained var.)
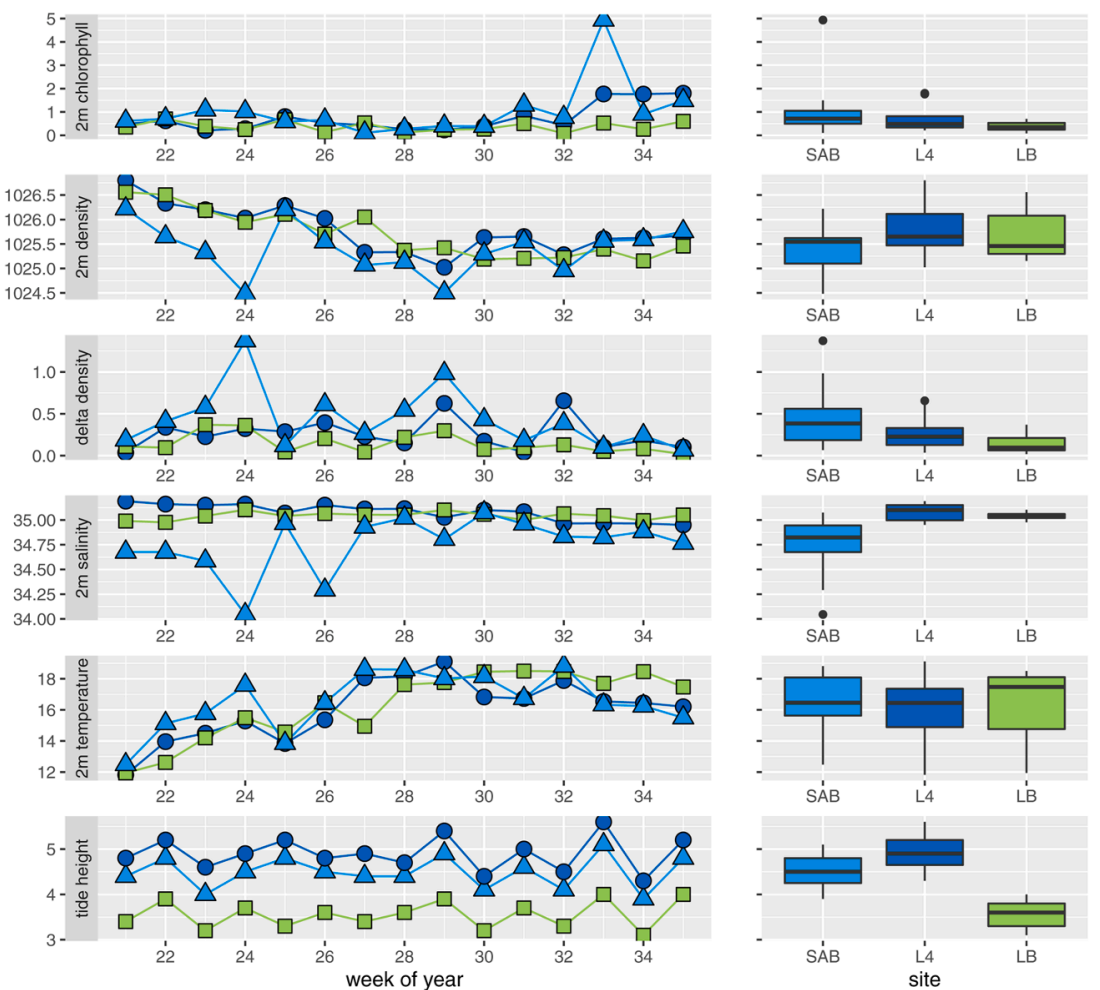

Fig. 2. Variation in physical parameters characterising the water column and chlorophyll concentrations at each survey site from week 21 to 35. Data represent Station 1 at each survey site: St Austell Bay (SAB) time series indicated by triangles, Plymouth (L4) indicated by circles and Lyme Bay (LB) indicated by squares. Principal Components Analysis (PCA): PC1 captures temporal changes across all three sampling sites in terms of water temperature, salinity and density. PC2 captures reduction in Chl- $a$ concentration and increase in Secchi depth at each site.
Table 2

Nutrient concentrations at the sampling sites of Plymouth L4, Lyme Bay and St Austell Bay.

\begin{tabular}{lllllll}
\hline Site & Date & $\begin{array}{l}\text { Nitrite } \\
\mu \mathrm{mol} L^{-} \\
1\end{array}$ & $\begin{array}{l}\text { Nitrate } \\
\mu \mathrm{mol} L^{-} \\
1\end{array}$ & $\begin{array}{l}\text { Ammonium } \\
\mu \mathrm{mol} L^{-1}\end{array}$ & $\begin{array}{l}\text { Silicate } \\
\mu \mathrm{mol} L^{-} \\
1\end{array}$ & $\begin{array}{l}\text { Phosphate } \\
\mu \mathrm{mol} L^{-1}\end{array}$ \\
\hline SAB & May & $<0.087$ & $<0.323$ & $<0.554$ & $<2.629$ & $<0.211$ \\
$\mathrm{SAB}$ & June & $<0.087$ & $<0.323$ & 1.109 & $<2.629$ & 0.390 \\
$\mathrm{SAB}$ & July & $<0.087$ & $<0.323$ & 0.665 & $<2.629$ & $<0.211$ \\
SAB & August & $<0.087$ & $<0.323$ & 0.554 & $<2.629$ & $<0.211$ \\
L4 & May & $<0.011$ & 0.031 & 0.100 & 0.499 & 0.100 \\
L4 & June & $<0.011$ & 0.050 & 0.200 & 0.499 & 0.100 \\
L4 & July & $<0.011$ & 0.050 & 0.299 & 0.100 & 0.100 \\
L4 & August & 0.011 & 0.100 & 0.499 & 2.000 & 0.100 \\
LB & May & $<0.087$ & $<0.323$ & $<0.554$ & $<2.629$ & $<0.211$ \\
LB & June & $<0.087$ & $<0.323$ & 0.998 & $<2.629$ & $<0.211$ \\
LB & July & $<0.087$ & $<0.323$ & 1.109 & $<2.629$ & $<0.211$ \\
LB & August & $<0.087$ & $<0.323$ & 0.665 & $<2.629$ & $<0.211$ \\
\hline
\end{tabular}

Concentrations represent average values for $2 \mathrm{~m}$ and $10 \mathrm{~m}$ water depth in each calendar month.
(FSA, 2021).

High biomass blooms were absent at LB (SI Figure S2); here phytoplankton biomass remained low $\left(6-57 \mathrm{mg} \mathrm{C} \mathrm{m}^{-3}\right)$ and was attributable mainly to the diatom Proboscia alata (SI Table S1a).

\subsubsection{Plankton community structure}

Phytoplankton communities at SAB and L4 were dominated in terms of biomass by dinoflagellates, including Karenia mikimotoi and Dinophysis spp. The short-lived K. mikimotoi bloom at SAB and L4 followed a notable increase in dinoflagellate:diatom ratio taking place two weeks earlier in week 21 at both SAB and L4 (SI Figure S3). The longer-term Dinophysis spp. bloom at SAB and L4 involved the sequential blooming of $D$. acuminata in May (week 21) followed by D. acuta in August (week 32); while their abundances at LB remained low $\left(<100\right.$ cells $\left.\mathrm{L}^{-1}\right)$. The key cilliate prey species for Dinophysis spp., Mesodinium rubrum, was on average more abundant ( $>200$ cells $\mathrm{L}^{-1}$ ) at SAB and L4 compared to LB $\left(<100\right.$ cells $\mathrm{L}^{-1}$ ), but abundance declined notably at the onset of the D. acuta bloom in week 32 (Fig. 4). This time point marked the depletion of $M$. rubrum at SAB, where a significant negative correlation was found between $D$. acuta and $M$. rubrum; Spearman rank correlation $S=859.56$, rho $=-0.5349324, p$-value $=0.0399$. 

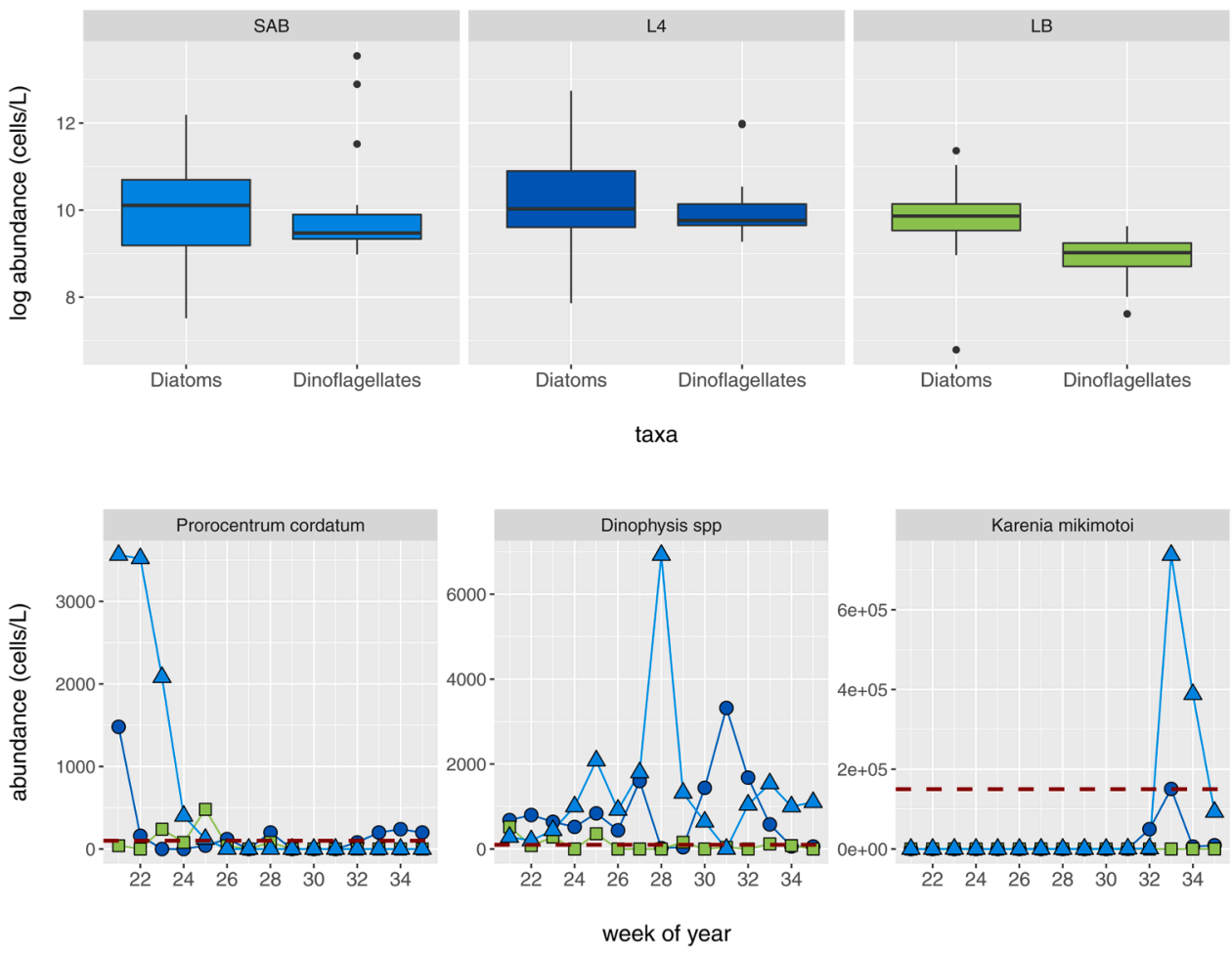

Fig. 3. Variation in phytoplankton including HAB species abundanceat each survey site from week 21 to 35 . Data represent Station 1 at each survey site: St Austell Bay (SAB) time series indicated by triangles, Plymouth (L4) indicated by circles and Lyme Bay (LB) indicated by squares.
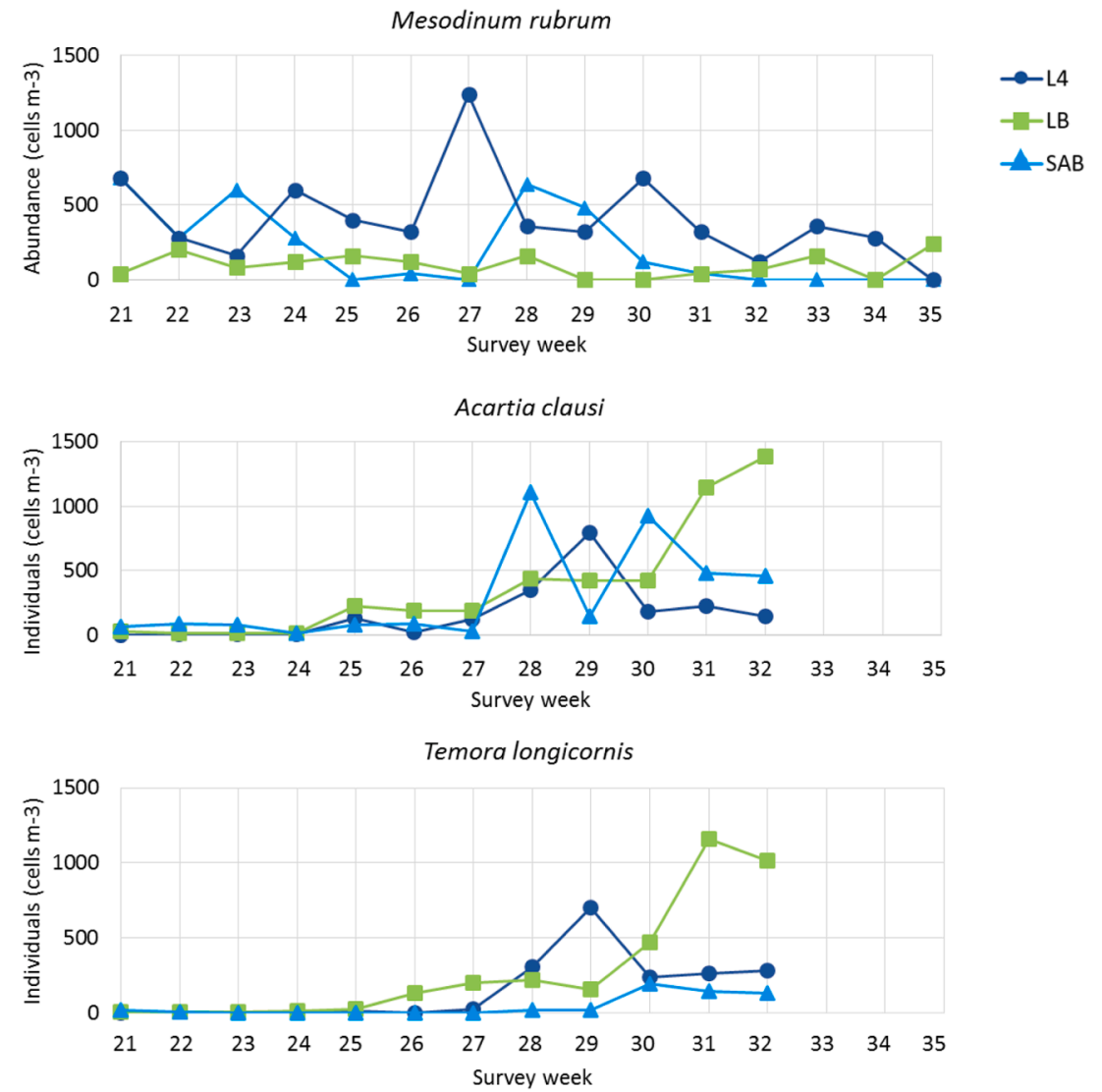

Fig. 4. Prey and Predator abundance for Dinophysis spp. at each survey site from week 21 to 35. Data represent Station 1 at each survey site: St Austell Bay (SAB) time series indicated by triangles, Plymouth (L4) indicated by circles and Lyme Bay (LB) indicated by squares. Prey: Mesodinum rubrum (ciliate). Predators: Acartia clausii; Temora longicornis (copepods). 
Phytoplankton species abundance was dominated by microflagellates (diameter $\sim 2 \mu \mathrm{m}, \sim 5 \mu \mathrm{m}$ ), which constituted 80 to $90 \%$ of total cell counts at all three sites (SI Table S1a). In particular, the nonHAB micro-flagellate Emiliania huxleyi reached significant numbers (up to $3.7 \times 10^{6}$ cells $\mathrm{L}^{-1}$ ) at L4 and SAB in week 27 (2nd July), but this species did not bloom at LB. Spatial and temporal variations in the biomass and abundance of phytoplankton species were evaluated by multivariate statistical analysis, employing Bray Curtis similarity analysis, followed by MDS ordination (SI Figure S3). Significant differences between sampling sites and sampling weeks were detected using pseudo F-tests in PERMANOVA and PERMDISP, respectively. Pairwise comparisons made in PERMANOVA $(p=0.001)$ confirmed that SAB, L4 and LB were all significantly different from each other with respect to phytoplankton species composition throughout the summer. According to SIMPER, sites were $\geq 28 \%$ dissimilar based on species $\times$ abundance (mainly micro-flagellate species) and $\geq 50 \%$ dissimilar based on species $\times$ biomass, with dinoflagellates including K. mikimotoi and Gyrodinium spirale, and diatoms including Probiscia alata and Chaetoceros socialis accounting for the biggest differences between sites (SI Table S1b). Environmental matching (BEST) for all three sampling sites found significant correlations between time-series data for phytoplankton community composition and environmental parameters: sea surface temperature; density; Secchi depth and Chl- $a$ (Spearman rank correlation $(n=45$, two tailed $)=0.386, p<0.05)$.

Zooplankton species abundance increased substantially over the course of the 2018 monitoring study at all three sampling sites. Maximum zooplankton abundance was recorded during a Noctiluca scintilans bloom in late July/August (weeks 30-34) at SAB and L4, whereas peaks in zooplankton abundance at LB were attributable to the copepods Acartia clausi and Temora longicornis (Fig. 4). Variation in zooplankton species abundance between sites and sampling weeks was evaluated by MDS ordination (SI Figure S4) and then confirmed using PERMANOVA and PERMDISP, respectively (Site $F_{\text {pseudo }(2,33)}=4.10, p$ $=0.001$; Week $\left.F_{\text {pseudo }(2,33)}=2.21, p=0.173\right)$. Pairwise comparisons made in PERMANOVA $(p<0.01)$ confirmed that zooplankton species composition differed significantly between all sites. According to SIMPER, sites were $\geq 56 \%$ dissimilar, and the abundance of Noctiluca scintillans, Arcartia calusii, Harpacticoida longipedia, Appendicularia spp., Cirripede nauplii and Podon spp. accounted for the biggest differences between sites (SI Table S2). LB was the most dissimilar site (62\% dissimilar to both L4 and SAB). Biota and Environmental matching (BEST) for all three sampling sites highlighted significant correlations between time-series data for zooplankton community composition and environmental parameters: sea surface temperature; density; Secchi depth and chlorophyll- $a$ (Spearman rank correlation $(n=36$, two tailed $)=0.365, p$ $<0.05)$.

\subsection{Analysis of temporal and wider spatial variations in HABs and oceanographical conditions}

\subsubsection{Historical occurrence of HABs and impacts at shellfish production sites}

HAB events have occurred repeatedly at the SAB and LB shellfish sites since they opened; since 2010 for $\mathrm{SAB}$ and since 2015 for $\mathrm{LB}$ (Table 3). HAB frequencies (expressed as\% of comparable weeks from 2015 to 2017, in which cell counts in surface water (2 m depth) exceeded advisory trigger levels) have been higher at SAB versus LB for K. mikimotoi (13\% versus 0\%), Dinophysis spp. (15\% versus $10 \%)$, Prorocentrum cordatum (11\% versus $6 \%$ ), Pseudo-nitzschia spp. (3\% versus $1 \%$ ) and for Alexandrium spp. (3\% versus 1\%). HAB frequencies are under-represented by the above FSA monitoring data (from 2015 onwards), because when cell counts in water exceed trigger levels, monitoring effort focusses primarily on the measurement of phycotoxins in shellfish and HAB cell counts are not reported during this time (FSA, 2019). According to both HAB species abundance and phycotoxin data, Dinophysis blooms are responsible for most HAB events in the region (FSA, 2019). Bloom intensities (cell abundances) have also been greater at SAB (and L4) in recent years compared to LB, most notably for Dinophysis spp. (Fig. 5). Furthermore, the frequency at which Dinophysis toxin concentrations in shellfish meat have exceeded EU regulatory action levels (\% of comparable weeks from 2015 to 2017, in which action levels ( $160 \mu \mathrm{g} \mathrm{kg}^{-1}$ okadaic acid equivalents) were exceeded) has also been higher at SAB (22\%) compared to LB (11\%) (Table 4). The levels of intoxication have also been substantially greater at SAB, consistent with higher Dinophysis spp. bloom intensities (Fig. 5). There have been no other toxin breaches in relation to other HAB species at SAB or LB (SI Table S3).

\subsubsection{Long-term trends in $H A B$ occurrence and abundance at $L 4$}

Long-term time series data for L4 (sampled each week from 1993 to 2018) show that several HAB species have bloomed regularly, with abundances generally peaking in the summer months (May to

Table 3

Exceedance of cell count trigger levels for HABs according to historical monitoring data for study sites and results from our 2018 study (in bold).

\begin{tabular}{|c|c|c|c|c|c|c|c|c|c|}
\hline \multirow[t]{2}{*}{ HAB species } & \multirow{2}{*}{$\begin{array}{l}\text { Trigger } \\
\text { level } \\
\text { (cells } L^{-} \\
{ }^{1} \text { ) }\end{array}$} & \multicolumn{8}{|c|}{ Number of weeks exceeding trigger level (\%) } \\
\hline & & $\begin{array}{l}\text { L4 - all year } \\
(1993-2017) / \\
1300 \text { weeks }\end{array}$ & $\begin{array}{l}\text { L4 - summer } \\
(2002-2017) / \\
256 \text { weeks }\end{array}$ & $\begin{array}{l}\text { L4 - } \\
\text { summer } \\
(2018) / 15 \\
\text { weeks }\end{array}$ & $\begin{array}{l}\text { SAB - all year } \\
(2010-2017) \\
\text { /416 weeks }\end{array}$ & $\begin{array}{l}\text { SAB - all year } \\
(2015-2017) \\
\text { /156 weeks }\end{array}$ & $\begin{array}{l}\text { SAB - } \\
\text { summer } \\
(2018) / 15 \\
\text { weeks }\end{array}$ & $\begin{array}{l}\text { LB - all year } \\
(2015-2017) / \\
156 \text { weeks }\end{array}$ & $\begin{array}{l}\text { LB - } \\
\text { summer } \\
(2018) / 15 \\
\text { weeks }\end{array}$ \\
\hline $\begin{array}{l}\text { Karenia } \\
\quad \text { mikimotoi }\end{array}$ & 150,000 & $22(1.7 \%)$ & $6(2.3 \%)$ & $1(6.7 \%)$ & $0(0 \%)$ & $0(0 \%)$ & $\begin{array}{l}2(13 \%) \\
2(13 \%)\end{array}$ & $0(0 \%)$ & $\begin{array}{l}0(0 \%) \\
0(0 \%)\end{array}$ \\
\hline $\begin{array}{l}\text { Pseudo- } \\
\quad \text { nitzschia spp. }\end{array}$ & 150,000 & $54(4.2 \%)$ & $28(10.9 \%)$ & $0(0 \%)$ & $15(4 \%)$ & $5(3.2 \%)$ & $\begin{array}{l}0(0 \%) \\
0(0 \%)\end{array}$ & $1(<1 \%)$ & $\begin{array}{l}0(0 \%) \\
0(0 \%)\end{array}$ \\
\hline $\begin{array}{l}\text { Noctiluca } \\
\text { scintillans }\end{array}$ & 150,000 & $16(1.2 \%)$ & $2(0.8 \%)$ & $3(20 \%)$ & $0(0 \%)$ & $0(0 \%)$ & $\begin{array}{l}0(0 \%) \\
2(13 \%)\end{array}$ & $0(0 \%)$ & $\begin{array}{l}0(0 \%) \\
0(0 \%)\end{array}$ \\
\hline $\begin{array}{l}\text { Phaeocystis } \\
\text { globosa }\end{array}$ & 150,000 & $52(4.0 \%)$ & $4(1.6 \%)$ & $0(0 \%)$ & $0(0 \%)$ & $0(0 \%)$ & $\begin{array}{l}0(0 \%) \\
0(0 \%)\end{array}$ & $0(0 \%)$ & $\begin{array}{l}0(0 \%) \\
0(0 \%)\end{array}$ \\
\hline Dinophysis spp. & 100 & $223(17 \%)$ & $162(63 \%)$ & $11(73 \%)$ & $42 *(10 \%)$ & $23 *(15 \%)$ & $\begin{array}{l}5 *(33 \%) \\
13(87 \%)\end{array}$ & $15^{*}(10 \%)$ & $\begin{array}{l}9(60 \%) \\
3(20 \%)\end{array}$ \\
\hline $\begin{array}{l}\text { Prorocentrum } \\
\text { cordatum }\end{array}$ & 100 & $185(14 \%)$ & $85(33 \%)$ & $5(33 \%)$ & $28(6.7 \%)$ & $17(11 \%)$ & $\begin{array}{l}4(27 \%) \\
4(27 \%)\end{array}$ & $9(5.8 \%)$ & $\begin{array}{l}2(13 \%) \\
2(13 \%)\end{array}$ \\
\hline $\begin{array}{l}\text { Protoceratium } \\
\text { reticulatum }\end{array}$ & 100 & $28(2.2 \%)$ & $41(16 \%)$ & $3(20 \%)$ & $0(0 \%)$ & $0(0 \%)$ & $\begin{array}{l}0(0 \%) \\
1(6.7 \%)\end{array}$ & $0(0 \%)$ & $\begin{array}{l}0(0 \%) \\
0(0 \%)\end{array}$ \\
\hline $\begin{array}{l}\text { Alexandrium } \\
\text { spp. }\end{array}$ & 40 & $8(0.6 \%)$ & $2(0.8 \%)$ & $0(0 \%)$ & $12(3 \%)$ & $4(2.6 \%)$ & $\begin{array}{l}3(20 \%) \\
0(0 \%)\end{array}$ & $2(1 \%)$ & $\begin{array}{l}0(0 \%) \\
0(0 \%)\end{array}$ \\
\hline
\end{tabular}

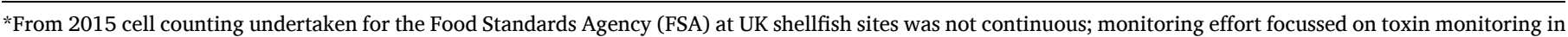
shellfish, after advisory trigger levels were breached. Therefore the frequency of cell count exceedances are under-reported at SAB and LB.

Frequency (\%) calculated as number breaches (weeks) / total time period (weeks) x 100 . 


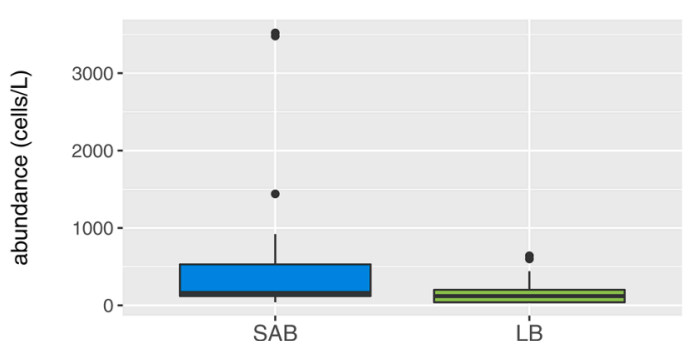

site

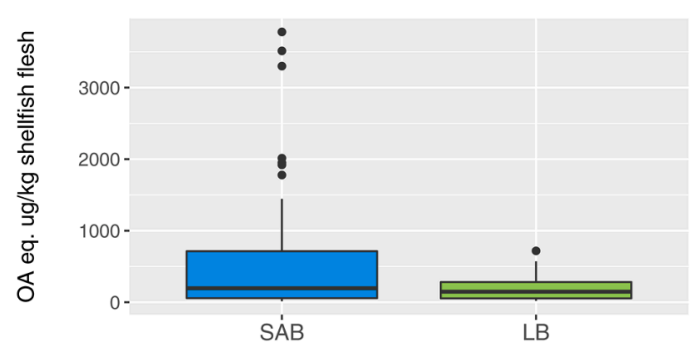

site

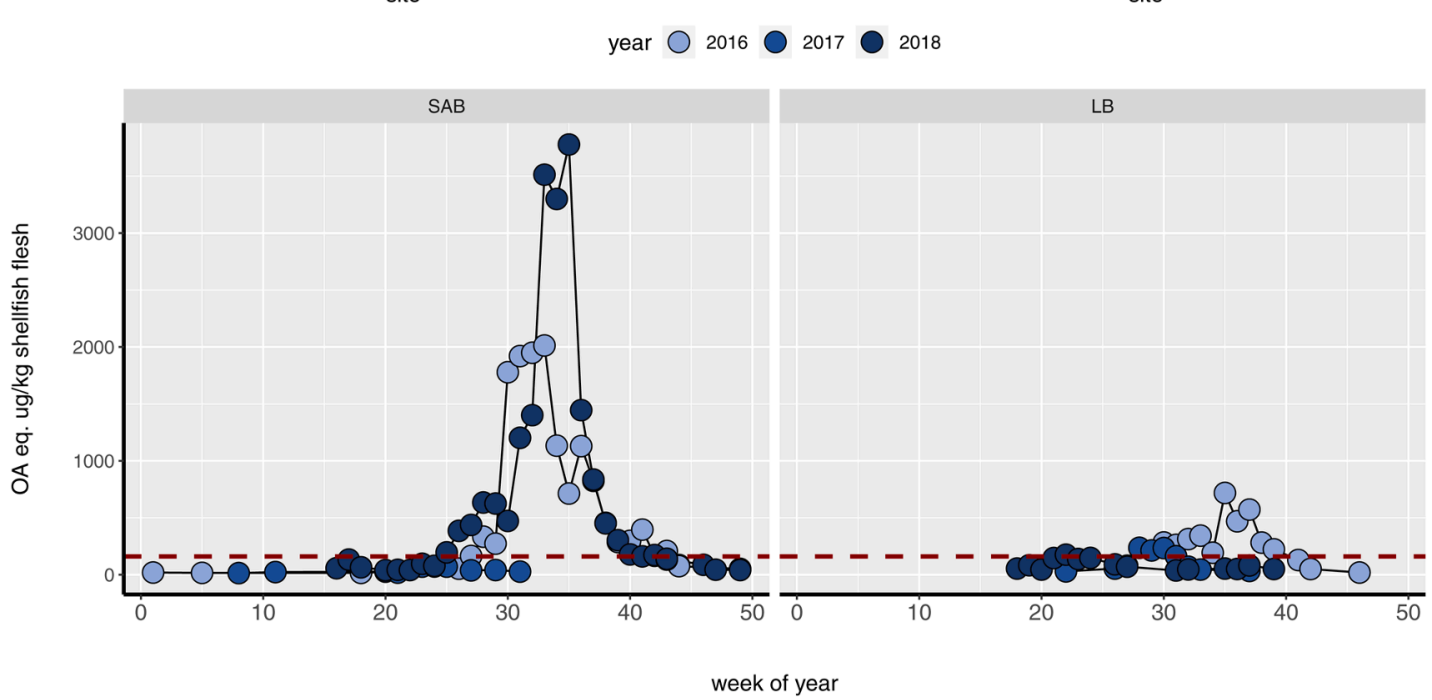

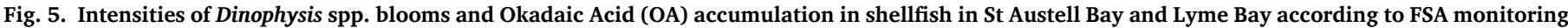
records for 2016 to 2018. Data represent Station 1 at each survey site in weeks 1-52 each year.

Table 4

Historical monitoring data for Dinophysis spp. cell count breaches versus toxins detected above action levels.

\begin{tabular}{|c|c|c|c|c|c|c|c|c|c|c|}
\hline \multirow[t]{2}{*}{ Year } & \multicolumn{2}{|c|}{ Plymouth (L4) } & \multicolumn{4}{|c|}{ St Austell Bay (SAB) } & \multicolumn{4}{|c|}{ Lyme Bay (LB) } \\
\hline & Period & $\begin{array}{l}\text { Cell count } \\
\text { breaches } \\
\text { (weeks) }\end{array}$ & Period & $\begin{array}{l}\text { Cell count } \\
\text { breaches } \\
\text { (weeks) }\end{array}$ & $\begin{array}{l}\text { Toxin } \\
\text { breaches } \\
\text { (weeks) }\end{array}$ & $\begin{array}{l}\text { Toxin detects } \\
\text { below action level } \\
\text { (weeks) }\end{array}$ & Period & $\begin{array}{l}\text { Cell count } \\
\text { breaches } \\
\text { (weeks) }\end{array}$ & $\begin{array}{l}\text { Toxin } \\
\text { breaches } \\
\text { (weeks) }\end{array}$ & $\begin{array}{l}\text { Toxin detects } \\
\text { below action level } \\
\text { (weeks) }\end{array}$ \\
\hline 2010 & $\begin{array}{l}\text { Feb- } \\
\text { Aug }\end{array}$ & 8 & Jun & 1 & 2 & 0 & & & & \\
\hline 2011 & $\begin{array}{l}\text { Mar- } \\
\text { Aug }\end{array}$ & 11 & Aug & 2 & 2 & 0 & & & & \\
\hline 2012 & $\begin{array}{l}\text { Mar- } \\
\text { Aug }\end{array}$ & 5 & $\begin{array}{l}\text { Apr- } \\
\text { Jul }\end{array}$ & 3 & 0 & 0 & & & & \\
\hline 2013 & $\begin{array}{l}\text { May- } \\
\text { Nov }\end{array}$ & 23 & $\begin{array}{l}\text { Jul- } \\
\text { Aug }\end{array}$ & 4 & 3 & 14 & & & & \\
\hline 2014 & $\begin{array}{l}\text { Jun- } \\
\text { Oct }\end{array}$ & 15 & $\begin{array}{l}\text { Jul- } \\
\text { Sep }\end{array}$ & 12 & 12 & 7 & & & & \\
\hline 2015 & $\begin{array}{l}\text { Mar- } \\
\text { Sep }\end{array}$ & 12 & $\begin{array}{l}\text { Jun- } \\
\text { Oct }\end{array}$ & $8^{*}$ & 16 & 5 & Aug & $2^{*}$ & 3 & 4 \\
\hline 2016 & $\begin{array}{l}\text { Mar- } \\
\text { Oct }\end{array}$ & 11 & $\begin{array}{l}\text { Jul- } \\
\text { Oct }\end{array}$ & $11^{*}$ & 17 & 7 & $\begin{array}{l}\text { Jul- } \\
\text { Sep }\end{array}$ & $10^{*}$ & 10 & 3 \\
\hline 2017 & $\begin{array}{l}\text { Mar- } \\
\text { Oct }\end{array}$ & 12 & $\begin{array}{l}\text { May- } \\
\text { Jun }\end{array}$ & 3 & 0 & 10 & $\begin{array}{l}\text { Jun- } \\
\text { Jul }\end{array}$ & $3 *$ & 4 & 6 \\
\hline 2010-17 & - & $86(24 \%)$ & - & $44(10 \%)$ & $52(13 \%)$ & $44(11 \%)$ & - & - & - & - \\
\hline 2015-17 & - & $24(15 \%)$ & - & $22(14 \%)$ & $33(22 \%)$ & $22(14 \%)$ & - & $15(9 \%)$ & $17(11 \%)$ & $13(8 \%)$ \\
\hline 2018 & $\begin{array}{l}\text { Apr- } \\
\text { Aug }\end{array}$ & $11(21 \%)$ & $\begin{array}{l}\text { Apr- } \\
\text { Aug }\end{array}$ & $\begin{array}{l}5^{*}(10 \%), 14^{\#} \\
(27 \%)\end{array}$ & $18(35 \%)$ & $13(25 \%)$ & $\begin{array}{l}\text { Apr- } \\
\text { Sep }\end{array}$ & $\begin{array}{l}9(17 \%), 5^{\#} \\
(10 \%)\end{array}$ & $1(2 \%)$ & $14(27 \%)$ \\
\hline
\end{tabular}

Official Control monitoring was administered for SAB and LB by the UK Food Standards Authority, under EU regulations (EC/854/2004).

SAB was licenced and opened in October 2009, LB was licenced in 2015.

*From 2015 cell counting performed by CEFAS/FSA was not continuous; monitoring effort focussed on toxin monitoring in shellfish, after toxin threshold was breached ( $>160 \mu \mathrm{g}$ okadaic acid equivalents per kg shellfish flesh). Therefore frequencies of cell count exceedances are under-reported at SAB and LB.

\# Data obtained from this research study. Frequency (\%) calculated as number breaches (weeks) / total time period (weeks) x 100. 
September) (SI Figure S5). Dinophysis spp. in particular has exceeded advisory trigger levels most often, i.e. $63 \%$ of weekly sampling events during summer months (May-August inclusive) in 2002-2017, and rising to $73 \%$ in 2018 (Table 3). Other dinoflagellate HAB species have also frequently exceeded trigger levels during the summers of 2002-2017 and in 2018 frequencies broke these historical records: K. mikimotoi (2.3\% increasing to $6.7 \%$ ); Noctiluca scintillans (1\% to $20 \%$ ); Protoceratium reticulatum (16\% to $20 \%$ ). Frequencies of trigger level exceedance for Prorocentrum cordatum reached 30\% in summer 2018, equalling historic records, while frequencies for the diatom HAB genus Pseudonitzschia spp. declined from a baseline of $10 \%$ to $0 \%$ in 2018 (Table 3). The bloom intensities (abundances) of some of these HAB species (particularly Prorocentrum cordatum) were also substantially higher in 2018 than previously recorded (SI Figure S5); this HAB species is epi-benthic, therefore routine water column sampling may underestimate bloom densities. It is also important to note that the toxigenic mechanism(s) of Prorocentrum cordatum, including shellfish poisoning mechanisms, remain largely unknown (Khanaychenko et al., 2019). For the majority of HAB species, there are significant positive correlations between cell abundances and water temperature at $10 \mathrm{~m}$ depth. This is according to Pearson correlations of untransformed (normal) data from the recent L4 time series (2002-2018), in which cell abundances and water temperature have been sampled concurrently (SI Figure S5). For Dinophysis spp. and Dinophysis acuta, the frequency of HAB events (i.e. number of weeks per year in which HAB cell abundances exceeded advisory trigger levels) were found to show significant positive correlations with periods of elevated water temperature (i.e. weeks $>15^{\circ} \mathrm{C}$ at $10 \mathrm{~m}$ depth) (Fig. 6). Furthermore, the decadal data from L4 (2002-2018) showed a significant negative correlation between the increasing abundance of Dinophysis acuta and declining abundance of its key prey species Mesodinium rubrum (Spearman correlation (paired samples): $S=261.21$, rho $=0.616$, p-value $=0.011$ ).

\subsubsection{Regional variation in $H A B$ occurrence and surface water circulation patterns}

The abundances of dinoflagellates, representing the majority of $\mathrm{HAB}$ species re-occurring regularly along the western English Channel coast, have been greater overall to the west compared to the east of Start Point (Fig. 3). The Start Point frontal region (Fig. 1) limited the extent of the eastward progression of the $K$. mikimotoi bloom along the Channel coast in August 2018, according to data from the FSA's wider monitoring network (SI Figure S6). Surface current velocities (net flows at $0 \mathrm{~m}$ and $15 \mathrm{~m}$ water depth) at the three study sites were generally found to be dominated by west to east components from 8 - 14 August one week prior to the K. mikimotoi bloom at SAB and L4 (SI Figure S7). Wider visualisation of surface currents (https://ovl.oceandatalab.com/) during this period showed the breakdown of cyclonic circulation (typical of seasonal thermohaline circulation) in western English Channel (Fernand et al., 2004; Hill et al., 2008; SI Table S4), leading to net directional surface flows from west to east between Lands End and Start Point. During the same period, cyclonic circulation broke down partially at $1 \mathrm{~m}$ and remained at $15 \mathrm{~m}$ depth in Lyme Bay (SI Figure S7).

Start Point was also clearly shown by Sentinel-3A OLCI to mark the eastern boundary of a major bloom of the non-HAB micro-flagellate coccolithophore Emiliania huxleyi in the western English Channel in the first two weeks of July (SI Figure 8). E. huxleyi was also detected in high numbers (up to 700000 cells $L^{-1}$ ) in water samples obtained from L4 in week 27 (2 July 2018) and was also detected at SAB in week 27 and week 28 ( 3 and 10 July 2018). Although E. huxleyi is not a HAB species, the extent of its influx is indicative of water circulation and the potential transport of other plankton species in the region.

\section{Discussion}

Our study coincided with the warmest, and one of the calmest, summers ever recorded in the UK and NW Europe. Sea surface

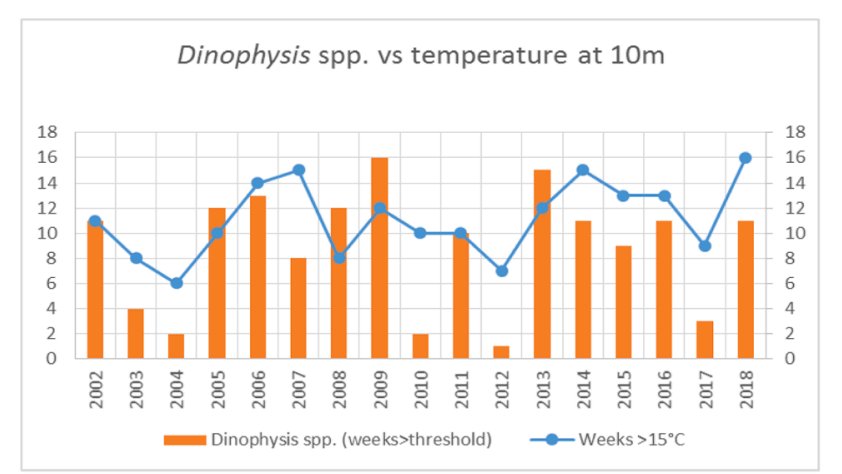

Spearman correlation (paired samples): $S=348.33$, rho $=0.488, \boldsymbol{p}$-value $=\mathbf{0 . 0 5}$

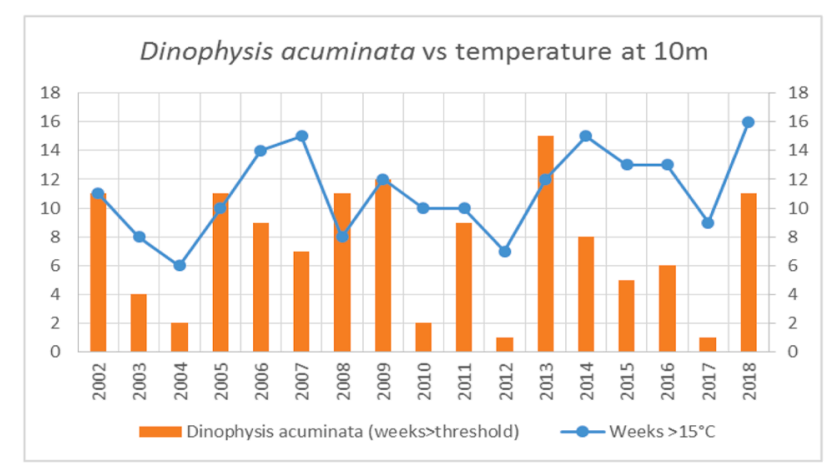

Spearman correlation (paired samples): $S=461.52$, rho $=0.361, p$-value $=0.08$

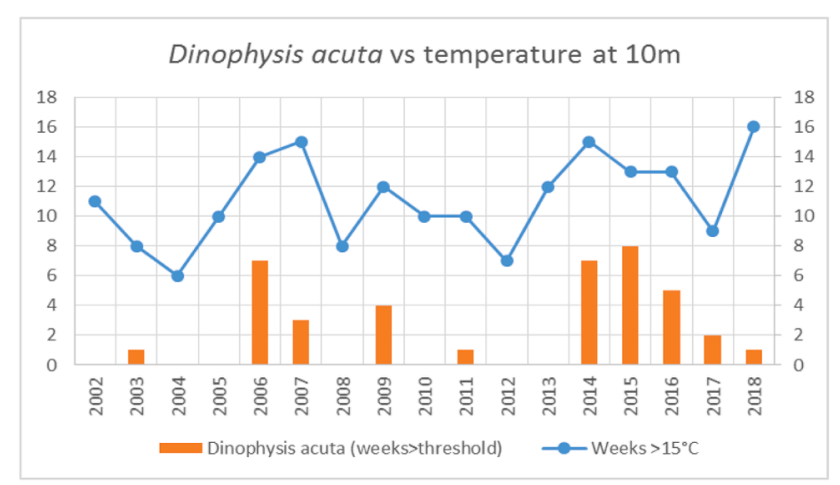

Spearman correlation (paired samples): $\mathrm{S}=261.21$, rho $=0.616, \boldsymbol{p}$-value $=\mathbf{0 . 0 1 1}$

Fig. 6. Correlations between incidences of Dinophysis species exceeding cell count trigger levels and corresponding periods of elevated water temperature at Plymouth (L4) from 2002 to 2018. Cell count trigger level = 100 cells $L^{-1}$

temperatures rose throughout the summer to $>18.5^{\circ} \mathrm{C}$ at $\mathrm{LB}$ and $\mathrm{SAB}$ and $>19^{\circ} \mathrm{C}$ at $\mathrm{L} 4$, reaching the highest temperature ever recorded at the Western Channel Observatory (WCO) in over 100 years (WCO, 2020). These exceptional conditions provided an ideal opportunity (see Trainer et al., 2020a) to investigate whether or not increased warming and thermal stratification in the western English Channel, projected under future climate change (UKCP18, Tinker et al., 2016), have the potential to expand niches for HABs both temporally and spatially. Our study found evidence of higher magnitude, more frequent and/or prolonged seasonal blooms of warm water dinoflagellates at two sites, SAB and L4, to the west of Start Point, but not at LB to the east. By employing standardised methods at established WCO and FSA monitoring sites, our study was able to build on substantial multi-decadal evidence of changes in plankton communities in the region, including increasing 
dinoflagellate:diatom ratios (Bedford et al., 2020) and the occurrence and impact on shellfish cultivation of dinoflagellate HABs, under increasingly prolonged stable, seasonally stratified conditions (Smyth et al., 2010; Hinder et al., 2011; Glibert et al., 2014;; Gobler et al., 2017; Schmidt et al., 2018a).

\subsection{Variation in HABs in relation to physical conditions}

Despite intense sea surface warming across all three survey sites in summer 2018, there were significant differences in plankton assemblages, including more frequent occurrences and higher abundances of dinoflagellate HAB species (exceeding trigger levels) at SAB and L4 compared to LB. In particular, the dinoflagellates Dinophysis acuminata and $D$. acuta formed blooms which were the largest and most persistent recorded to date at SAB and L4, and the accumulation of Dinophysis toxins in farmed mussels at SAB led to an 18 week shellfish harvesting ban, costing $>£ 1$ million in lost sales. Greater prevalence of Dinophysis spp., and several other dinoflagellate HAB species at SAB and L4, was consistent with increased water column density stratification (see Barton et al., 2015; Lucas et al., 2016), which is known to occur to the west of the tidal mixing front located off Start Point (Pingree et al., 1983; Boalch 1987). To the east of this frontal system, in Lyme Bay, greater tidal mixing is more favourable for diatom blooms (Smayda and Trainer, 2010). These contrasting hydrodynamic regimes and associated phytoplankton communities were evident in 2018, according to environmental survey data for our three study sites. In addition, other more extensive spatial data confirmed that Start Point $\left(\sim 4^{\circ} \mathrm{W}\right)$ marked the eastward extent of high biomass blooms of the non-HAB micro-flagellate coccolithophore $E$. huxleyi detected in early June by Sentinel 3A satellite imagery, and the dinoflagellate $\mathrm{HAB}$ species $\mathrm{K}$. mikimotoi detected in mid-August by the FSA's network of monitoring stations along the western English Channel. According to a regional-scale assessment of the surface current velocities, based on the CMEMS data (CMEMS, 2020), the K. mikimotoi bloom to the west of Start Point coincided with the temporary reversal of seasonal thermohaline circulation (typically running east to west) and the incursion of cooler, nutrient enriched water from the Western Approaches to the English Channel. Meanwhile to the east of Start Point at LB, sea surface temperature remained elevated at $17.7-18.5^{\circ} \mathrm{C}$ and $K$. mikimotoi did not bloom there.

Our results are consistent with previous studies, which have shown considerable spatial heterogeneity in HAB occurrence in the region, in association with frontal systems (Pingree et al., 1975; Holligan et al., 1979; Hartman et al., 2014; Barnes et al., 2015). For example, K. mikimotoi most often blooms along the western boundary of the seasonally stratified western English Channel, (Pingree, 1975, Holligan, 1979, Garcia and Purdie, 1994; Widdicombe et al., 2010; Barnes et al., 2015). Another factor which has been associated with increasing occurrence of $\mathrm{HAB}$, including K. mikimotoi and Dinophysis spp., is their physical advection and concentration against the coast in sheltered stratified areas (Raine, 2014; Gillibrand et al., 2016; Schmidt et al., 2018b). However, our survey data build on accumulating evidence that Dinophysis spp. and other HABs can also bloom regularly offshore along the western English Channel (Widdicombe et al., 2010), in the wider English Channel, North Sea (Edwards et al., 2019) and elsewhere along the NW European shelf, for example along the Galician coast (Diaz et al., 2019). The regular offshore occurrence of HAB cell counts above advisory trigger levels at L4 and wider English Channel indicates a notable risk for future offshore expansion of shellfish mariculture in the region.

\subsection{Variation in HABs in relation to bio-geochemical conditions}

Nutrient levels (and chlorophyll concentrations of $<1 \mathrm{mg}$ Chl- $\mathrm{m}^{-}$ ${ }^{3}$ ) were below the long-term seasonal average in the summer of 2018 (Smyth et al., 2010) and in this respect conditions were uniform across our three survey sites for much of the summer. These conditions favoured low biomass, motile dinoflagellate HABs, including Dinophysis spp., with the ability to exploit available light and inorganic nutrients for photosynthesis, and also to prey upon other plankton (mixotrophy) (Anderson et al., 2012; Zhang et al., 2013; Lucas et al., 2016). As well as greater stratification favouring more intense and more prolonged Dinophysis blooms at SAB and L4, the greater abundance of a key prey species Mesodinium rubrum ( $\geq 100$ cells $L^{-1}$ at SAB and L4 compared to $\leq 20$ cells $L^{-1}$ at $\mathrm{LB}$ ) also likely contributed to the enhanced survival and population growth of Dinophysis spp. (via acquisition of chloroplasts for autotrophic growth) (Park et al., 2006, 2008). Significant correlation between Dinophysis acuta (but not Dinophysis acuminata) and Mesodinium rubrum abundance in the long-term data (1992-2018) from L4 provided further evidence of the importance of this trophic relationship. Elsewhere Mesodinium spp. has been associated with $D$. acuminata, but not with $D$. acuta, for example in coastal fjords of southern Chile. However, in this alternative example other factors also contributed to niche differentiation between these Dinophysis species; $D$. acuta was associated with higher salinity compared to $D$. acuminata (i.e. 23-25 psu compared to $17-20 \mathrm{psu}$ ), and with lower levels of turbulence and Photosynthetically Active Radiation (PAR) (Baldrich et al., 2021). At each of our coastal survey sites salinity remained within 33.5-35 psu throughput the water column, so the environmental niches at our sites were not comparable with those in Chile. Discriminating niches for these species is important in shellfish waters, since $D$. acuta and $D$. acuminata may produce different profiles of DSP toxins (OA, DTX and PTX toxins) and profiles have been shown to vary between geographical regions (Reguera et al., 2014; Baldrich et al., 2021).

Plankton grazing and parasitism can also play key roles in regulating the abundance of marine planktonic micro-algae, including HAB species (Chambouvet et al., 2008; Jones et al., 2011; Montagnes et al., 2008; Sun et al., 2018). Spatial and temporal variations in phytoplankton and zooplankton grazers were detected in our study. At LB, there were substantially higher numbers of copepod grazers, such as Acartia clausi, and Temora longicornis (Fig. 4), which can exert considerable grazing pressure on phytoplankton, such as Dinophysis spp., in European shelf seas, including the western English Channel (Carlsson et al., 1995; Maneiro et al., 2000; Kozlowsky-Suzuki et al., 2006). The diet of A. clausii, in particular, may contain up to $30 \%$ D. acuminata (Carlson et al., 1995). Shellfish such as mussels (Mytilus edulis), farmed in SAB and $\mathrm{LB}$, can also exert considerable grazing pressure on both phytoplankton and zooplankton, removing up to $30 \%$ of total plankton biomass in embayed sites with extended water residence times, such as SAB (Newell, 2004; Lucas et al., 2016; Nielsen et al., 2016; Cranford, 2019). Biomass removal by shellfish is estimated to be substantially less $(\sim 5 \%)$ in deeper, more open coastal waters with shorter residence times, such as LB (Torres pers. comm.). Under conditions of low primary productivity in summer 2018, farmed mussels at LB showed substantially lower growth and condition compared to those at SAB (J. Holmyard, G. Rawle pers. comms.). Higher mussel growth at SAB did not appear to inhibit the blooming of Dinophysis spp. or K. mikimotoi, nor did these blooms appear to have a negative effect on mussel growth. The effects of filter feeding shellfish on plankton community composition, including the abundance of $\mathrm{HAB}$ species, (and vice versa), are generally poorly understood (Newell, 2004; Petersen et al., 2008; Lucas et al., 2016). Nevertheless, some bivalve shellfish, including blue mussels (Mytilus edulis), can show preferential uptake of HAB cells and may deposit intact live cells or dormant cysts to underlying sediments, from which they may be re-suspended (Hégaret et al., 2007). The comparative abundance of Dinophysis spp. and other HAB cells or cysts in underlying sediments at $\mathrm{SAB}$ and $\mathrm{LB}$ has not been quantified to date.

\section{Conclusions}

Gaining insights on the likely frequency and extent of HABs under future climate change scenarios, particularly in rapidly warming NW European shelf seas, is critically important for planning the expansion of mariculture for the sustainable production of healthy, nutritious 
seafood. Our study coincided with the exceptionally warm summer of 2018 and provided an ideal opportunity to investigate if increased warming and thermal stratification in the western English Channel has the potential to expand niches for HABs. Despite widespread warm and stable conditions, coupled with low levels of inorganic nutrients throughout the region, favouring warm water dinoflagellate HAB species, we detected distinct differences in the magnitude, spatial extent and duration of HABs. HABs were more pronounced and prolonged in coastal and offshore areas to the west compared to the east of the Start Point tidal mixing front $\left(\sim 4^{\circ} \mathrm{W}\right)$. Differences either side of this frontal system in water circulation patterns and plankton assemblages, including zooplankton grazers, were linked to the observed variations in the extent and duration of $\mathrm{HAB}$ events. Furthermore, the increasing magnitude and duration of HABs with rising sea surface temperature to the west of Start Point was highlighted by long-term data from Plymouth L4. Here dinoflagellate HABs, including Dinophysis spp., Prorocentrum cordatum, Protoceratium reticulatum, Noctiluca scintillans and Karenia mikimotoi, formed the most prominent blooms recorded since records began in 1992. These contemporary trends and survey data for 2018 provide a glimpse into possible future climate change scenarios. However, should warming of over $3^{\circ} \mathrm{C}$ occur, as projected from 1960 to 1989 to 2069-2089 in UK shelf seas (Tinker et al., 2016), thermal niches for some HABs may be confined below the thermocline in the summer, to other seasons or to higher latitudes, allowing other species to take their place. Therefore, even in a warmer more stable future, changes in plankton species distributions, phenologies and interactions are likely to continue to make $\mathrm{HAB}$ prediction challenging.

\section{Declaration of Competing Interest}

The authors declare that they have no known competing financial interests or personal relationships that could have appeared to influence the work reported in this paper.

\section{Acknowledgements}

This research was funded by the European Marine Fisheries Fund, grant numbers ENG2360 and ENG3103 to ARB, JS, CL and CRT. Station L4 plankton and environmental data were provided by the Plymouth Marine Laboratory (PML) Western Channel Observatory www.weste rnchannelobservatory.org.uk, which was funded as part of the UK's Natural Environmental Research Council's National Capability Longterm Single Centre Science Programme, grant number NE/R015953/1. Sentinel-3A ocean and land colour images (OLCI) were provided from PRIMROSE (Predicting the Impact of Regional Scale Events on the Aquaculture Sector, www.shellfish-safety.eu), Interreg Atlantic Area programme, grant number: EAPA 182/2016. FSA HAB monitoring data were supplied by Elizabeth Bear, Alex Milligan and Myriam Algoet from the Centre for Environment Fisheries and Aquaculture Science (CEFAS). Fieldwork was conducted by ARB, MKSL, GR and JH, with sample analysis by AM, PR, CW, and MKSL. ARB and MKSL analysed the data. The manuscript was written by ARB and MKSL with contributions from all authors. We'd like to thank Victor Martinez Vicente and the crew of PML's RV Quest for sample collection at Plymouth L4, and to Offshore Shellfish and Westcountry Mussels of Fowey for facilitating sample collection in Lyme Bay and St Austell Bay respectively.

\section{Supplementary materials}

Supplementary material associated with this article can be found, in the online version, at doi:10.1016/j.hal.2021.102166.

\section{References}

Anderson, D.M., 2012. HABs in a changing world: a perspective on harmful algal blooms, their impacts, and research and management in a dynamic era of climactic and environmental change. Harmful Algae 2012, 3-17.

Anderson, D.M., Cembella, A.D., Hallegraeff, G.M., 2012. Progress in understanding harmful algal blooms: paradigm shifts and new technologies for research, monitoring, and management. Ann. Rev. Marine Sci. 4, 143-176.

ASIMUTH (2014). Applied simulations and Integrated modelling for the understanding of toxic and harmful algal blooms. Final Report Summary, FP7-SPACE Project ID: 261860.

Baldrich, A.M., Pérez-Santos, I., Álvarez, G., Reguera, B., Fernández-Pena, C., RodríguezVillegas, C., Araya, M., Álvarez, F., Barrera, F., Karasiewicz, S., Díaz, P.A., 2021. Niche differentiation of Dinophysis acuta and D. acuminata in a stratified fjord. Harmful Algae 103, 102010. https://doi.org/10.1016/j.hal.2021.102010.

Barnes, M.K., Tilstone, G.H., Smyth, T.J., Widdicombe, C.E., Gloël, J., Robinson, C., Kaiser, J., Suggett, D.J., 2015. Drivers and effects of Karenia mikimotoi blooms in the western English Channel. Prog. Oceanogr. 137, 456-469. https://doi.org/ 10.1016/j.pocean.2015.04.018.

Barton, A.A., Lozier, M.S., Williams, R.G., 2015. Physical controls of variability in North Atlantic phytoplankton communities. Limnol. Oceanogr. 60, 181-197. https://doi. org/10.1002/lno.10011.

Bedford J., Ostle C., Johns D.G., Atkinson A., Best M., Bresnan E., Machairopoulou M., Graves C.A., Devlin M., Milligan A., Pitois S., Mellor A., Tett P., McQuatters-Gollop A. (2020). Lifeform indicators reveal large-scale shifts in plankton across the NorthWest European shelf. Glob Chang Biol., published online, doi: 10.1111/gcb.15066.

Boalch, G.T., 1987. Changes in the phytoplankton of the western English Channel in recent years. British Phycol. J. 22, 225-235. https://doi.org/10.1080/ 00071618700650291.

Brown, A.R., Lilley, M., Shutler, J., Lowe, C., Artioli, A., Torres, R., Berdalet, E., Tyler, C. R., 2019. Assessing risks and mitigating impacts of harmful algal blooms on mariculture and marine fisheries. Rev. Aquaculture 1-26. https://doi.org/10.1111/ raq. 12403 .

BS EN 15204:2006 Water quality - Guidance standard on the enumeration of phytoplankton using inverted microscopy (Utermöhl technique).

Buck, B.H., Troell, M.F., Krause, G., Angel, D.L., Grote, B., Chopin, T., 2018. State of the art and challenges for offshore integrated multi-trophic aquaculture (IMTA). Front. Mar. Sci. 5, 165-176. https://doi.org/10.3389/fmars.2018.00165.

Carlsson, P., Granéli, E., Finenko, G., Maestrini, S.Y., 1995. Copepod grazing on a phytoplankton community containing the toxic dinoflagellate Dinophysis acuminata. J. Plankton Res. 17 (10), 1925-1938.

Chambouvet, A., Morin, P., Marie, D., Guillou, L., 2008. Control of toxic marine dinoflagellate blooms by serial parasitic killers. Science 322, 1254-1257.

Clarke, K.R., Gorley, R.N., Somerfield, P.J., Warwick, R.M., 2014. Change in Marine communities: an Approach to Statistical Analysis and Interpretation. Primer-E Ltd.

CMEMS (2020). Copernicus Marine Environment Monitoring Service Product Identifier MULTIOBS_GLO_PHY_REP_015_004, URL (accessed April 2020): https://resources. marine.copernicus.eu/?option=com_csw\&task=results?option=com_csw\&view $=$ details\&product $\mathrm{id}=$ MULTIOBS GLO PHY REP 015004.

Coates L., Morris S., Algoet M., Higman W., Forster R., Stubbs B. (2009). A karenia mikimotoi bloom off the southern coast of cornwall in august 2009: the results from the biotoxin monitoring programme for England and Wales. Cefas Contract Report.

Cranford, P.J., 2019. Magnitude and extent of water clarification services provided by bivalve suspension feeding. In: Smaal, AC, Ferreira, JG, Grant, J, Petersen, JK, Strand, Ø (Eds.), Goods and Services of Marine Bivalves. Publ. Springer, Switzerland, pp. 119-142.

Davidson, K., Miller, P.I., Wilding, T.A., Shutler, J., Bresnan, E., Kennington, K., Swan, S., 2009. A large and prolonged bloom of Karenia mikimotoi in Scottish waters in 2006. Harmful Algae 8, 349-361.

Davidson, K., Gowen, R.J., Harrison, P.J., Fleming, L.E., Hoagland, P., Moschonas, G., 2014. Anthropogenic nutrients and harmful algae in coastal waters. J. Environ. Manage. 146, 206-216.

Dees, P., Bresnan, E., Dale, A.C., Edwards, M., Johns, D., Mouat, B., Whyte, C., Davidson, K., 2017. Harmful algal blooms in the Eastern North Atlantic Ocean. Proc. Natl. Acad. Sci. U S A. 2017 Nov 14; 114 (46), E9763-E9764.

DEFRA (2017). Seafood 2040: a strategic framework for England (http://www.seafish. org/media/publications/SEAFOOD_2040_lo_singlep_071217.pdf).

Diaz, P.A., Reguera, B., Moita, T., Bravo, I., Ruiz-Villarreal, M., Fraga, S., 2019. Mesoscale dynamics and niche segregation of two dinophysis species in galicianportuguese coastal waters. Toxins (Basel) 11, 37. https://doi.org/10.3390/ toxins11010037.

EA, Environment Agency, 2019. National Laboratory Services. UK Environment Agency. URL (accessed November 2019): http://natlabs.co.uk/our-services/water-ana lysis/chemical-tests-suites/.

Edwards, M., Stern, R., Graham, G., 2019. A report on additional and add-on enhancements for the continuous plankton recorder survey programme including add-on variables and molecular analysis. Optimising and Enhancing the Integrated Atlantic Ocean Observing Systems AtlantOS -633211. Report D2.9 CPR Add-on variables.

FAO, Food and Agriculture Organization, 2018. The State of World Fisheries and Aquaculture 2018: Meeting the Sustainable Development goals' Food and Agriculture Organization of the United Nations. UN FAO, Rome, p. 200. - URL (accessed 25 August 2019). http://www.fao.org/3/i9540en/I9540EN.pdf.

Fernand, L., Raine, R., Dye, S., McCloghrie, P., Chambers, C.E., Lyons, S., Wooltorton, J., 2004. Circulation of the Western English Channel: A combination of Factors. Centre 
for Environment, Fisheries and Aquaculture Science (CEFAS). URL (accessed April 2020). https://www.cefas.co.uk/publications/posters/31317web.pdf.

Froehlich, H.E., Smith, A., Gentry, R.R., Halpern, B.S., 2017. Offshore aquaculture: i know it when I See It. Front Mar Sci 4, 154. https://doi.org/10.3389/ fmars.2017.00154.

FSA, Food Standards Agency, 2019. Phytoplankton and Biotoxin Results For England and Wales. Food Standards Agency Open Data archive. URL (accessed November 2019). https://data.food.gov.uk/catalog/datasets? search=shellfish\&years=all\#results.

FSA, Food Standards Agency (2021). Phytoplankton monitoring. URL (accessed December 2021): https://www.food.gov.uk/business-guidance/biotoxin-and-phyto plankton-monitoring\# phytoplankton-monitoring.

Garcia, V.M., Purdie, D.A., 1994. Primary production studies during a Gyrodinium cf. aureolum (Dinophyceae) bloom in the western English Channel. Mar. Biol. 119 (2), 297-305.

Gillibrand, P.A., Siemering, B., Miller, P.I., Davidson, K., 2016. Individual-based modelling of the development and transport of a Karenia mikimotoi bloom on the North-west European continental shelf. Harmful Algae 53, 118-134.

Glibert, P.M., Allen, I.J., Artioli, Y., Beusen, A., Bouwman, L., Harle, J., Holmes, R., Holt, J, 2014. Vulnerability of coastal ecosystems to changes in harmful algal bloom distribution in response to climate change: projections based on model analysis. Glob. Chang. Biol. 20, 3845-3858.

Gobler, C.J., Doherty, O.M., Hattenrath-Lehmann, T.K., Griffith, A.W., Kang, Y., Litaker, R.W., 2017. Ocean warming since 1982 has expanded the niche of toxic algal blooms in the North Atlantic and North Pacific oceans. Proc. Nat. Acad. Sci. USA 114 (19), 4975-4980.

Gobler, C.J., 2020. Climate Change and Harmful Algal Blooms: insights and perspective. Harmful Algae 91, 101731.

Gowen, R.J., Tett, P., Bresnan, E., Davidson, K., McKinney, A., Milligan, S., Mills, D.K., Silke, J., Harrison, P., Crooks, A.M., 2012. Anthropogenic nutrient enrichment and blooms of harmful micro-algae. Oceanogr. Marine Biol. 50, 65-126.

Hallegraeff, G.M., 2010. Ocean climate change, phytoplankton community responses, and harmful algal blooms: a formidable predictive challenge. J. Phycol. 46 (2), 220-235.

Hartman, S.E., Hartman, M.C., Hydes, D.J., Smythe-Wright, D., Gohin, F., Lazure, P., 2014. The role of hydrographic parameters, measured from a ship of opportunity, in bloom formation of Karenia mikimotoi in the English Channel. J. Mar. Syst. 140, 39-49. https://doi.org/10.1016/j.jmarsys.2014.07.001.

Hégaret, H., Wikfors, G.H., Shumway, S.E., 2007. Diverse feeding responses of five species of bivalve mollusc when exposed to three species of harmful algae. J. Shellfish Res. 26, 549-559.

Hill, A.E., Brown, J., Fernand, L., Holt, J., Horsburgh, K.J., Proctor, R., Raine, R., Turrell, W.R., 2008. Thermohaline circulation of shallow tidal seas. Geophys. Res. Lett. 35, L11605. https://doi.org/10.1029/2008GL033459.

Hinder, S.L., Hays, G.C., Brooks, C.J., Davies, A.P., Edwards, M., Walne, A.W., Gravenor, M.B., 2011. Toxic marine microalgae and shellfish poisoning in the British Isles: history, review of epidemiology, and future implications. Environ. Health 10, 54.

Holm-Hansen, O., Lorenzen, C.J., Holmes, R.W., Strickland, J.D.H., 1965. Fluorometric determination of chlorophyll. Conseil International pour l'Exploration de la Mer. Journal du Conseil 301, 3-15.

Jones, K.L., Mikulski, C.M., Barnhorst, A., Doucette, G.J., 2011. Comparative analysis of bacterioplankton assemblages from Karenia brevis bloom and non-bloom water on the west Florida shelf (Gulf of Mexico, USA) using16S rRNA gene clone libraries. FEMS Microbiol. Ecol. 73, 468-485.

Kendon, M., McCarthy, M., Jevrejeva, S., Matthews, A., Legg, T., 2019. State of the UK Climate 2018. Int. J. Climatol. 39 (S1), 1-55.

Khanaychenko, A.N., Telesh, I.V., Skarlato, S.O., 2019. Bloom-forming potentially toxic dinoflagellates Prorocentrum cordatum in marine plankton food webs. Protistology 13 (3), 95-125.

Kozlowsky-Suzuki, B., Carlsson, P., Rühl, A., Granéli, E., 2006. Food selectivity and grazing impact on toxic Dinophysis spp. by copepods feeding on natural plankton assemblages. Harmful Algae 5 (1), 57-68.

Lucas L.V., Cloern J.E., Thompson J.K., Stacey M.T., Koseff J.R. (2016). Bivalve grazing can shape phytoplankton communities. Front. Mar. Sci. 10.3389/fmars.2016.00014.

Maneiro, I., Frangópulos, M., Guisande, C., Fernández, M., Reguera, B., Riveiro, I., 2000. Zooplankton as a potential vector of diarrhetic shellfish poisoning toxins through the food web. Mar. Ecol. Prog. Ser. 201, 155-163.

Manfrin, C., De Moro, G., Torboli, V., Venier, P., Pallavicini, A., Gerdol, M., 2012. Physiological and molecular responses of bivalves to toxic dinoflagellates. Invertebrate Survival Journal 9, 184-199.

Menden-Deuer, S., Lessard, E.J., 2000. Carbon to volume relationships for dinoflagellates, diatoms, and other protist plankton. Limnol. Oceanogr. 45, 569-579. https://doi.org/10.4319/10.2000.45.3.0569.

Mitchell, S., Rodger, H., 2007. Pathology of wild and cultured fish affected by a Karenia mikimotoi bloom in Ireland, 2005. Bulletin-Eur. Ass. Fish Pathologists 27, 39-42.

Montagnes, D.J.S., Chambouvet, A., Guillou, L., Fenton, A., 2008. Responsibility of microzooplankton and parasite pressure for the demise of toxic dinoflagellate blooms. Aquat. Microb. Ecol. 53, 211-225.

Newell, R.I.E., 2004. Ecosystem influences of natural and cultivated populations of suspension-feeding bivalve molluscs: a review. J. Shellfish Res. 23 (1), 51-61.

Nielsen, P., Cranford, P.J., Maar, M., Petersen, J.K., 2016. Magnitude, spatial scale and optimization of ecosystem services from a nutrient extraction mussel farm in the eutrophic Skive Fjord, Denmark. Aquac Environ Interact 8, 311-329. https://doi. org/10.3354/aei00175.
Park, M.G., Kim, S., Kim, H.S., Myung, G., Kang, Y.G., Yih, W., 2006. First successful culture of the marine dinoflagellate Dinophysis acuminata. Aquat. Microb. Ecol. 45, 101-106.

Park, M.G., Park, J.S., Kim, M., Yih, W., 2008. Plastid dynamics during survival of Dinophysis caudata without its ciliate prey. J. Phycol. 44, 1154-1163.

Petersen, J.K., Hansen, J.W., Laursen, M.B., Clausen, P., Carstensen, J., Conley, D.J., 2008. Regime shift in a coastal marine ecosystem. Ecol. Appl. 18, 497-510.

Pingree, R.D., Pugh, P.R., Holligan, P.M., Forster, G.R., 1975. Summer phytoplankton blooms and red tides along tidal fronts in the approaches to the English Channel. Nature 258, 672-677.

Pingree, R.D., Mardell, G.T., Maddock, L., 1983. A marginal front in Lyme Bay. J. Marine Biol. Assoc. United Kingdom 63, 9-15.

R Core Team, 2017. R: A language and Environment For Statistical Computing. $\mathrm{R}$ Foundation for Statistical Computing, Vienna, Austria. URL. https://www.R-project. org/.

Raine, R., O’Boyle, S., O'Higgins, T., White, M., Patching, J., Cahill, B., McMahon, T., 2001. A satellite and field portrait of a Karenia mikimotoi bloom off the south coast of Ireland, August 1998. Hydrobiologia 465, 187-193.

Raine, R., 2014. A review of the biophysical interactions relevant to the promotion of HABs in stratified systems: the case study of Ireland. Deep-Sea Res. II 101, 21-31.

Reguera, B., Riobó, P., Rodríguez, F., Díaz, P.A., Pizarro, G., Paz, B., Franco, J.M. Blanco, J., 2014. Dinophysis Toxins: causative Organisms, Distribution and Fate in Shellfish. Mar. Drugs 12 (1), 396-461.

Rio, M.-.H., Mulet, S., Picot, N., 2014. Beyond GOCE for the ocean circulation estimate: synergetic use of altimetry, gravimetry, and in situ data provides new insight into geostrophic and Ekman currents. Geophys. Res. Lett. 41, 2014. https://doi.org/ 10.1002/2014GL061773.

S-3 EuroHAB, 2019. Project S-3 EUROHAB to Monitor Harmful Algal Blooms from Space. EU Interreg Programme. URL (accessed December 2020): https://interreg5a-fce.eu /en/news-and-events/news/project-s-3-eurohab-to-monitor-harmful-algal-blooms-fr om-space/.

Schmidt, W., Evers-King, H.L., Campos, C.J.A., Jones, D.B., Miller, P.I., Davidson, K., Shutler, J.D., 2018a. A generic approach for the development of short-term predictions of E. coli and biotoxins in shellfish; application to a coastal bay and an estuary. Aquac Environ. Interact 10, 173-185.

Schmidt, W., Raymond, D., Parish, D., Ashton, I., Miller, P.I., Campos, C.J.A., Shutler, J., 2018b. Design and operation of a low-cost and compact autonomous buoy system for use in coastal aquaculture and water quality monitoring. Aquacult. Eng. 80C, 28-36.

Sharples, J., Simpson, J.H., 2019. Shelf sea and shelf slope fronts. Encycloped. Ocean Sci. (Third Edition) 1, 24-34.

Sherwin, T.J., Jonas, P.J.C., 1994. The impact of ambient stratification on marine outfall studies in british waters. Mar. Pollut. Bull. 28, 527-533.

Silke, J., O'Beirn, F., Cronin, M., 2005. Karenia mikimotoi: an exceptional dinoflagellate bloom in Western Irish waters, summer 2005. Marine Environment and Health Series No. 21. Marine Institute, p. 2005.

Smayda, T.J., Trainer, V.L., 2010. Dinoflagellate blooms in upwelling systems: seeding, variability, and contrasts with diatom bloom behaviour. Prog. Oceanogr. 85, 92-107.

Smyth, T.J., Fishwick, J.R., Al-Moossawi, L., Cummings, D.G., Harris, C., Kitidis, V., Rees, A., Martinez-Vicente, V., Woodward, E.M.S., 2010. A broad spatio-temporal view of the western English Channel observatory. J. Plankton Res. 32, 585-601. https://doi.org/10.1093/plankt/fbp128.

Smyth, T., Atkinson, A., Widdicombe, S., Frost, M., Allen, I., Sims, D., Barange, M., 2015. The UK Western Channel Observatory: integrating pelagic and benthic observations in a shelf sea ecosystem. Prog. Oceanogr. 137 (B), 335-570.

Sun, R., Sun, P., Zhang, J., Esquivel-Elizondo, S., Wu, Y., 2018. Microorganisms-based methods for harmful algal blooms control. Ann. Rev. Biores. Technol. 248 (Pt B), $12-20$.

Tinker, J., Lowe, J., Holt, J., Pardaens, A., Barciela, R., 2016. Uncertainty in climate projections for the 21st century northwest European shelf seas. Prog. Oceanogr. 148, 56-73.

Trainer, V.L., Moore, S.K., Hallegraeff, G., Kudela, R.M., Clement, A., Mardones, J.I., Cochlan, W.P., 2020a. Pelagic harmful algal blooms and climate change: lessons from nature's experiments with extremes. Harmful Algae 91, 101591. https://doi. org/10.1016/j.hal.2019.03.009.

Trainer, V.L., Davidson, K., Wakita, K., Berdalet, E., Suddleso, M., Myre, G., Trethewey, D., 2020b. GLOBALHAB: evaluating, reducing and mitigating the cost of Harmful Algal Blooms: a compendium of case studies. PICES Press 28 (1), 30-32.

UKCP018. UK Climate Projections (2018). UK Meterological Office https://ukclimate projections.metoffice.gov.uk/.

Utermöhl, H., 1958. Zur vervollkommnung der quantitativen phytoplankton-methodik. Mitteilungen der Internationale Vereinigung für Theoretische und Angewandte Limnologie 9, 1-38.

WCO (2020). Western Channel Observatory. URL (accessed March 2020): http://www. westernchannelobservatory.org.uk.

Weisberg, R.H., Liu, Y., Lembke, C., Hu, C., Hubbard, K., Garrett, M., 2019. The coastal ocean circulation influence on the 2018 West Florida shelf K. brevis red tide bloom. J. Geophys. Res.: Oceans 124 (4), 2501-2512. https://doi.org/10.1029/ 2018JC014887.

Wells, M.L., Trainer, V.L., Smayda, T.J., Karlson, B.S.O., Trick, C.G., Kudela, R.M., Ishikawa, A., Bernard, S., Wulff, A., Anderson, D.M., Cochlan, W., 2015. Harmful algal blooms and climate change: learning from the past and present to forecast the future. Harmful Algae 49, 68-93. https://doi.org/10.1016/j.hal.2015.07.009.

Wells, M.L., Karlson, B., Wulff, A., Kudela, R., Trick, C., Asnaghi, V., Berdale, E., Cochlan, W., Davidson K De Rijcke, M., Dutkiewicz, S., Hallegraeff, G., Flynn, K.J., Legrand, C., Paerl, H., Silke, J., Suikkanen, S., Thompson, P., Trainer, V.L., 2020. 
Future HAB science: directions and challenges in a changing climate. Harmful Algae 91, 101632. https://doi.org/10.1016/j.hal.2019.101632.

Widdicombe, C.E., Eloire, D., Harbour, D., Harris, R.P., Somerfield, P.J., 2010. Long-term phytoplankton community dynamics in the western English Channel. J. Plankton Res. 32, 643-655.
Zhang, Q.-.C., Song, J.-.J., Yu, R.-.C., Yan, T., Wang, Y.F., Kong, F.-.Z., Zhou, M.-.J.,

2013. Roles of mixotrophy in blooms of different dinoflagellates: implications from the growth experiment. Harmful Algae 30, 10-26. 